\title{
A WINDOW INTO PAPUA'S PAST : ARCHAEOLOGICAL AND ANTHROPOLOGICAL STATUS QUO IN THE STAR MOUNTAINS (Melihat Masa Lalu Papua : Penelitian Arkeologi dan Antropologi di Pegunungan Bintang)
}

\author{
Wulf Schiefenhövel ${ }^{1,2}$, Marian Vanhaeren' \\ ${ }^{1}$ Max-Planck-Institute, Human Ethology Group, Seewiesen-Starnberg, Germany \\ 2UMR 5199 PACEA, CNRS, University of Bordeaux, France
}

\begin{tabular}{l} 
INFO ARTIKEL \\
\hline Histori Artikel \\
Diterima: 7 Juli 2017 \\
Direvisi: 14 Juli 2017 \\
Disetujui: 30 Oktober 2017 \\
\hline
\end{tabular}

Keywords:

ABSTRACT

Papua,

archaeology,

anthropology,

Star Mountains

In this paper, which is based on anthropological fieldwork in the Province of Papua, and literature research in archaeology and anthropology, we attempt to give an overview over the present status of research in Tanah Papua, with special focus on the prehistory and anthropology of groups in the interior, especially on the little known "Ok-Mek Minisphere" as well as on the potential routes of prehistoric migration to New Guinea and into the Star Mountains.

\begin{abstract}
ABSTRAK
Tulisan didasarkan pada penelitian lapangan antropologi di Papua, dan penelitian kepustakaan arkeologi dan antropologi. Dalam penelitian ini mencoba untuk memberikan gambaran mengenai perkembangan penelitian saat ini di Papua, dengan fokus pada prasejarah dan antropologi di pedalaman, terutama di wilayah "OkMek" yang sangat potensial sebagai jalur migrasi prasejarah ke New

Guinea dan masuk ke Pegunungan Bintang.
\end{abstract}

Kata kunci:

Papua,

arkeologi,

antropologi,

Pegunungan Bintang

\section{PREHISTORY REACHING INTO OUR DAYS}

Papuan cultures in the interior of western New Guinea (Figure 1) became visible to outside observers only a few decades ago. The Dani were an early focus of scientists with Broekhuijse (1967), Gardner and Heider (1969), Heider (1970) and others. The neighbouring Jalé/Yali were first studied by Klaus-Friedrich Koch $(1967,1974)$. A first contact to a southern Mek group was established during one of the early Dutch group of land surveyors and scientists who met members of a population they named "Goliath" (unfittingly: male average body length was well below $150 \mathrm{~cm}$ ) according to a then newly discovered mountain in the area (de Kock, 1912). The history of contact with the Eipo in the centre of the Mek group of languages and cultures and with their neighbours is much shorter. The members of the French-Dutch expedition, which crossed Papua from south to north, were the first outsiders to contact central Mek groups on both sides of the mountain range during their 5-months expedition (Saulnier, 1960; Gaisseau, 1961; Delloye, 1977; Sneep, 2005). An Indonesian military expedition, whose members parachuted into the Eipomek (then " $X$ ") Valley, made friendly contact to the local people (Tandjung, 
1969; Hariono, 2003). Eipomek was also the centre of the interdisciplinary German Research Team (GRT), which, starting in 1974, carried out fieldwork in this area in cooperation with LIPI (Koch, 1977; Schiefenhövel, 1976, 1979, 1982, 1991; Ploeg, 2004).

The Ngalum/ Nalum, westernmost representatives of the OK culture and language groups who live in the area of Oksibil, todays quickly developing centre of the Star Mountains Regency, were first studied in the course of a Dutch interdisciplinary research project in 1959 (Brongersma and Venema, 1960; Pouwer, 1964) and were competently described by Hylkema (1974), a Catholic priest, who had lived many years with them in Abmisibil. On the Papua New Guinean side work among the Highland and Lowland Ok started in the 1960ies (cp. Healy, 1964). The densely populated Wahgi Valley further east was already discovered by Michael Leahy and his brother Danny in 1933 (Leahy and Craine, 1937; see also Craig, 1967). Highland New Guinea was, as Souter (1963) called it, the 'Last Unknown': its people lived in prehistory.

\section{ARCHAEOLOGICAL AND}

\section{ANTHROPOLOGICAL STATUS QUO}

Researchers agree (cp. O'Connel and Allen, 2004; 2015 the respective authors in Pawley et al. 2005; Mellars, 2006; Rabett, 2012; Mellars et al. 2013, Wright et al. 2013; Dennell and Porr, 2014) that the first groups of modern
Homo sapiens, having left Africa perhaps around 100,000 BP, arrived, 40,000 - 50,000 BP, possibly earlier (Oppenheimer, 2014), at the shore of the New Guinean mainland. Until that time this large island, the other islands of Melanesia, Polynesia and Micronesia were uninhabited by Homo sapiens. Homo erectus lived on Java (Dubois, 1894; von Koenigswald, 1955; Sémah, 1986; Sémah, A.-M. et al. 2004; Marwick, 2009; Polanski et al. 2016) and a dwarf mutation of this species Homo floresiensis (Brown et al. 2004, Morwood et al. 2004, van den Berg et al. 2016a), in Flores (perhaps also on Sulawesi, van den Bergh et al. 2016b) from the Middle until the Late Pleistocene. These presapiens species did, however, as far as is known today, not cross the water channels to New Guinea, nor to Australia. As Papuan languages are still present on some of the Eastern Indonesian Islands (Figure 1) e.g. on Alor, Timor, Ternate, Tidore and North-Eastern Halmahera, one may assume that the first anatomically modern humans who came along this route, spoke Papuan languages similar to those spoken by todays inhabitants of the interior of New Guinea, most of the south coast and most stretches of the north coast of the big island (cp. Wurm, 1960; McElhanon and Voorhoeve, 1970; Pawley, 2005; Ross, 2005). In Melanesia, the Austronesians have, much later, from approximately 4,000 BP on, successfully settled mainly at some coastal stretches or islands near the Bird's Head (e.g. Fakfak, Sorong, Aru 
Island), on the islands at New Guinea's north coast (e.g. Biak, Serui, Manus), parts of the Eastern Tip and especially in archipelagos east of mainland New Guinea (Kirch, 2010; Spriggs, 2011). After originally arriving in the regions of todays Indonesian Provinces of Papua Barat and Papua and mixing with the local Papuan people, these mixed Austronesian-Papuan groups became the ancestors of the Polynesians (Kayser et al., 2006, 2008).

How the first Papuan migrants crossed the Wallace Line, the Weber Line and the Lydekker Line (Figure 1) is uncertain. Possibly they used simple rafts, perhaps they knew, from partly migrating along the coasts of Arabia, India, Asia and South East, how to build boats. Whatever facilitated their journey over 40 or more $\mathrm{km}$ of open Ocean, they did it. It is interesting to note that modern DNA, research has not found much connection between the Australian Aborigines and the Papuans, even though they are thought to have migrated to western Oceania around the same time (Stoneking and Wilson, 1989; van Dijk, 2005).

In its long shrouded history, enigmatic New Guinea must have been the sceneofanumberofdramaticchanges in human life. What role the extraordinary climate change from the peak, the waning and the disappearance of the last glacial period may have played is little known. It must have been a period of cultural adaptation, perhaps also of different populations being more successful than others in shaping their hunter-gatherer strategies to the respective conditions. The archaeologically little searched soil of New Guinea has released lithic artefacts, which are completely unknown to the present populations. Weapons made of stone, mostly deadly effective club heads of various shapes (Swadling, 1983; Craig and Hyndman, 1990), are as unknown to the present-day Papuans as they are for the visiting researcher; often they are kept as sacred objects. They may stem from very ancient times and do not tell us much more than that the people of those days must have been as aggressive warriors, as the Papuans have been until recently. Stone mortars and pestles (Swadling, 1983; Egloff, 2008), often zoomorphic and of extraordinary beauty, are found on the former shores and further surrounds of the mid-Holocene floodplains of the Sepik-Ramu inland sea (Swadling and Hide, 2005) and were possibly used for pounding taro into a glutinous kind of dough, which when cooked or steamed in an earth oven, gives a truly delicious meal. Perhaps mortar and pestles were (also) used for crushing nutritious oilcontaining Pandanus conoideus into a ketchup-like sauce, which provides one of the rare sources of plant fat in the diet of the Highland Papuans. These puzzling artefacts are probably associated with neolithic gardening and arboriculture. Taro (Colocasia esculenta and other species), sugar cane (Saccharum officinarum), sago (Metroxylon sp.) and other cultivars are genuine Papuan food 
plants. The domestication of taro started about 8,000 BP or even earlier (Golson, 1976; Denham 2005, 2011).

\section{THE INTERIOR OF PAPUA: ALMOST ARCHAEOLOGICAL TERRA INCOGNITA}

The oldest human settlements in New Guinea (Bobongara 44,000 BP and Ivane Valley $42,000 \mathrm{BP}$ ), both situated in the eastern region of Papua New Guinea (PNG) as well as others on islands of the Bismarck Archipelago and at the north coast of Papua New Guinea (Denham et al. 2003, Fairbairn et al. 2006, Wright et al. 2013, Summerhayes and Ford, 2014) show how fast the early Papuan groups migrated into their new territory.

In the Province of Papua only one very old palaeontological site $(32,000$ BP), without traces of human existence, has been reported by Hope and Haberle (2005). Indirect evidence comes from microcharcoal from lake and swamp cores (core A Kosipe Swamp, 36,500 \pm 400 BP OZE-451 (Fairbairn et al., 2006), Wamena in the Balim, $>33,000$ BP (Hope, 1998, 2007; Haberle, 2003) which are attributed to fires made by humans.

Compared to the eastern half of the island, where 7 sites older than 25,000 BP (Figure 2) have been excavated so far and signs of human inhabitation have been found, Papua and Papua Barat are, with exception of Pasveer's (2004), archaeological study in the Toe Cave near Ayamaru, which found signs of human activity at about $26,000 \mathrm{BP}$, still archaeological terra incognita with regard to early prehistory.

It is, of course, likely that the early Papuans inhabited the western half of the big island at least as early as the dates known from PNG, as their first migration most probably happened from west to east, whereas the later settling of the highlands may perhaps have also comprised a movement from east (e.g. along the Sepik River, Swadling, 1981) to west (Ok, Mek and Yali/Dani ethnic groups, cp. Schiefenhövel 2014).

The last ice age (until approximately 10,000 BP) affected Mainland and Island New Guinea, temperatures were probably at least about $2-3^{\circ} \mathrm{C}$, possibly up to $7^{\circ} \mathrm{C}$ lower than now (Hope and Haberle, 2005). Today, permanent settlements in the New Guinea Highlands are usually not exceeding 2,200 $\mathrm{m}$ above sea level, gardens are made up to that range as well, only occasionally slightly higher, but are then subject to occasional adverse conditions, including frosts.

Given that the temperature gets approximately half a degree lower per each $100 \mathrm{~m}$ altitude one can estimate, if temperatures were $2-3^{\circ}$ lower than today, that the early Papuans could have permanently lived at an altitude of about 1,600 - 1,800 m above sea level; this is the range of some of the very early archaeological sites in PNG, where geology, climate and other determinants of the environment are very similar to Papua and Papua Barat. Some of the old sites however are 
situated above 2,000 m (Summerhayes and Ford, 2014), suggesting a lesser difference in temperature between today and those early settlements. This would be in contradiction with Hope and Haberle (2005), who suggest that the temperatures during the height of the last Ice Age might have been up to $7^{\circ} \mathrm{C}$ lower than today. In that case, the early Papuans most probably would have lived in altitudes lower than 1,700 $\mathrm{m}$, but might have visited higher areas for hunting and collecting; just as today they hunt and snare small marsupials in altitudes up to $4,000 \mathrm{~m}$ during the day and stay the night in the protection of rock shelters where they can make fires and sleep in the dry (Schiefenhövel 2015). The low tropical forest, savannahtype vegetation, mountain forest and alpine forest (Hope and Haberle, 2005) provided a large array of fauna and flora which supported the subsistence of the early Papuan inhabitants who most probably were living in mobile groups just as e.g. the inhabitants of the foothills north of the Mek Region, close to the Mamberamo (Idenburgh/Taritatu) River today.

One can therefore assume that the highlands (and indeed also the non-submerged coasts of today) of Papua and Papua Barat contain many hitherto undiscovered archaeological sites, which, one could say, just wait to be researched by specialists. Members of the Archaeological Office of Papua (Balai Arkeologi Papua) have carried out fieldwork in two caves (Gua Mendalbuk,
Gua Maria) and one burial niche near Oksibil, the capital of the Star Mountains Regency, and collected surface finds there (stone adzes, human bones and personal ornaments, Maryone and Tolla, 2011, Maryone, 2012). No other archaeological research has so far been conducted in this interior part of Papua. Quite a large amount of archaeological fieldwork, on the other hand, has been carried out, mainly by members of the Balai Arkeologi, in other regions of the Provinces of Papua and Papua Barat (for a summary see Mahmud and Suroto, 2012).

\section{EARLY HUNTER-GATHERERS IN AN ALPINE COUNTRY AND A CRADLE OF AGRICULTURE}

Hope and Haberle (2005) summarize available findings on the prehistory of human life in New Guinea by stating that the plains were inhabited by about 50,000 BP, upland New Guinea by about $30,000 \mathrm{BP}$. There are only the few very ancient archaeological sites mentioned above (Figure 2). It is likely that the more findings will be made in future, the more this already very early time line will be pushed back. In light of the original dispersal of Homo sapiens out of Africa believed by some researchers (e.g. Stringer, 2011) to have happened only around 60,000 BP or even later, there is a serious problem: How could modern humans have arrived in New Guinea and Australia or in Sulawesi about the same time when they (according to these hypotheses) 
were just leaving their African homeland? This contradiction, like others, most likely will be solved with the remarkable advances in the sciences involved, from palaeontology to molecular genetics.

Hope G. and Haberle S. (2005) and Hope G. and Aplin K. (2007) also throw light on the very special geographic and zoological situation of the Sahul Shelf, the former continent comprising Australia, New Guinea and some smaller islands, before the last ice age came to its end about $14,000 \mathrm{BP}$, and describe the unusual fauna of New Guinea including several large mammal species which lived at the time people first arrived. They state (op. cit: p. 544): "Several cave and swamp sites of the central highlands of the island contain bones of extinct taxa, principally species of large kangaroos (Protemnodon spp.) and diprotodontids (for example Hulitherium, Zygomaturus and Maokopia). For example a calf-sized diprotodontid, Maokopia ronaldii has been recovered from Kwiyawagi in central Irian Jaya where it seems to have been adapted to extensive subalpine grasslands. It lived until perhaps 30,000 year ago, but no association of its remains with human artefacts has been found. However, fire is apparent around 33,000 years ago in the Balim Valley, the same catchment as the fossil (Hope, 1998). The subalpine fauna seems to have disappeared well before the climate warmed after 14,000 BP at which time forest limits rose and grasslands diminished. Hence some other cause (which may include hunting or disturbing) must be involved.

This would be another of the cases where early humans eradicated animal species with lithic weapons; the Maori of New Zealand inflicted that fate on to the flightless Moa birds (Holdaway and Jacomb, 2000). These incidences and participant observation of traditionally living peoples around the world teach us that these palaeolithic and neolithic "children of nature" do not live in sacred harmony with their environment. Tools and weaponry, that is technology, and especially nowadays the offer of money and other goods, decide how much damage is done to nature. Humans are maximizers, and their time horizon for planning is limited; the wellbeing of grandchildren is taken into account, the further future is hardly ever considered. This evolutionary constraint seems to affect modern economy and politics as well.

Jack Golson (2005) quotes Susan and Ralph Bulmer (1964: 7274) who proposed "...a three-phase sequence for Highlands prehistory: an initial hunter-gatherer phase; a phase of technological and economic change associated with agriculture based on Indo-Pacific staples like taro, yam and banana; and a final phase characterised by the introduction within the last few hundred years of tropical American sweet potato, the present staple of Highlands agriculture". The first two phases are basically undisputed. Most likely the early Papuans lived of foraged food (some of the collecting strategies, 
i.e. utilizing insects, larvae and other "minimal protein" sources, were still in place among the Eipo in modern times (Schiefenhövel and Blum, 2007) and about $8,000 \mathrm{BP}$ or earlier the neolithic "revolution" took place in highland New Guinea where taro, Colocasia esculenta (cf. the unfortunately illmanaged UNESCO World Heritage site at Kuk, Wahgi Valley, Papua New Guinea), yams (Dioscorea ssp.), sugar cane (Saccharum officinarum), it close relative, the delicious Saccharum edule (sayur lilin in Bahasa Indonesia, pitpit in Neomelanesian Pidgin) and several protein containing vegetables were domesticated (Schiefenhövel, 2013). Indeed, this part of the world was, besides the extraordinarily productive Americas, and besides Asia and the Fertile Crescent, one of the very few important cradles of agriculture.

THE INTRODUCTION OF THE SWEET POTATO - STILL UNRESOLVED

The third phase of the sequence described by Susan and R. Bulmer (1964) is more uncertain. Most researchers assume that the introduction of sweet potato (Ipomoe batatas), one of the many products of Amerindian domestication (another one coming to New Guinea was tobacco, Nicotinea tabaccum, cf. Hays, 1991), entered New Guinea after the conquista through Spanish and/or Portuguese contacts. Polly Wiessner (2005) correlates her findings for Enga oral history, namely that informants report, for the time of about 350 years ago, social upheavals, more warfare, massive changes in the distribution of ethnic groups etc., to the advent of the new crop. The first white visitors entering the highlands valleys were amazed by the sheer size of the very well laid out and carefully groomed sweet potato gardens. It is obvious that their "green hands", i.e. a long history of horticulture and rich experience with domesticated plants, soils, climate zones etc. have made the mountain Papua one of the most successful neolithic horticulturist populations worldwide. The simple, but very effective agricultural techniques they employed have yielded harvests, which could not be improved without fertiliser and metal tools (Plarre, 1978). This is especially true concerning the sweet potato (see also Suroto, 2013, on sweet potato cultivation in the Balim/ Baliem Valley).

While many researchers adhere to a post-conquista time schedule for the introduction of Ipomoea batatas to New Guinea, it is, however, established that the kumar, as the sweet potato is called in Peruvian Quechua (and kumara on some Polynesian Islands!), had reached Oceania around 700 AD (van Tilburg, 1994). Research by Caroline Roullier and Doyle McKey (pers. comm. 2011) which included samples collected in Eipomek in 2008, does not rule out the possibility that cultivars of Ipomoea batatas have been grown in Highland New Guinea for much longer than 350 years. Terence Hays (2005) points to the fact that the number and distribution of 
terms for sweet potato and tobacco are very different, so that it is well possible that the former came to Melanesia much earlier than the latter. The astounding variety of sweet potato cultivars in highland New Guinea gardens (Hiepko and Schiefenhövel, 1987) is another indication that Ipomoea batatas is known and cultivated by Papuan peoples much longer than a few hundred years ago. Scaglion and Soto (1994) also argue, on the basis of terms for the sweet potato in West-New Guinean languages, that the new food plant was not brought through a western (Portuguese/Spanish), but via an eastern route; that would support an advent of this important tuber through Polynesia, independent from and probably considerably earlier than the conquista.

For the prehistory of highland New Guinea this hitherto unresolved issue is of considerable importance. Did the Mountain Papuans carry out the revolutionary change of their subsistence strategy from difficult to multiply taro to easily grown sweet potato only about 350 BP or much earlier? All researchers are in agreement that this new crop must have had many important repercussions on their daily lives, probably on population size, wars and customs like preferential female infanticide, a very effective way of controlling population growth which was still in place until about 1980 in the central Mek area (Schiefenhövel, 1989).

\section{EPIDEMIOLOGICAL AND OTHER HEALTH FACTORS}

How much the advance into the rugged but epidemiologically favourable higher mountains was influenced by endemic or epidemic diseases (cp. Sinnet and Whyte, 1973) typical for lowland tropics is a very interesting question, which has not been addressed sufficiently. As mentioned above, some prehistorians estimate the arrival of humans in the subalpine regions of New Guinea to have happened at around 30,000 BP, whereas Pamela Swadling (1981, 1983) puts the settlement of highland New Guinea around 10,00017,000 BP. This concurs with the disappearance of the last massive ice age and the fact that higher altitudes would then have offered more hospitable conditions for humans. This important issue, when precisely the highlands were settled, must remain open until new archaeological and other facts come to light. A late settlement scenario does not at all rule out occasional or regular hunting expeditions of pre-horticultural Papuans into the higher mountain ranges where they would have spent the nights with possible frost and snowfall in the protection of rock shelters. As mentioned, this survival strategy is still going on today.

In the Mek region the malaria line was, in the 1970ies, at approximately $1,600 \mathrm{~m}$ above sea level; it has gone up already due to global warming. Other tropical diseases also are temperature dependent, e.g. yaws (Framboesia), 
caused by a syphilis related but Ok, the Mek, the Yali and the Dani live not sexually transmitted bacterium (Treponema pallidum pertenue); below the malaria line down to altitudes tropical dysentery diseases are also temperature, i.e. altitude, sensitive. It is, therefore, easy to understand that at begin of colonial rule towards the end of the $19^{\text {th }}$ century, by far the majority of New Guinea's population lived in the highlands - and remained undiscovered for a long time.

From the viewpoint of human biology it is important to note that when the Eipo came into contact with the researchers of the German Research Team in 1974, they were surprisingly healthy (Schiefenhövel, 1982) and very well adapted to life in the precarious zones of high altitude with very little animal protein (insects were a typical, important food for women and children, Schiefenhövel and Blum, 2007), low temperatures and a very rugged terrain demanding extremely athletic performance which everyone, especially the women, subjected and still subject themselves to every day: carrying loads of $40 \mathrm{~kg}$, equal to their own body weight, for hours, with a smile on their face - an unthinkable performance in the developed part of the world. Contact to the modern world has led, in the last 30 years, to dangerous infections with global diseases, especially tuberculosis (often already resistant to standard medication), HIVIAIDS and other sexually transmitted diseases. This constitutes a veritable challenge for the health system.

Surprisingly, a small part of the

of around $1,000 \mathrm{~m}$, in the case of lowland Ok even 400 m (Craig and Hyndman, 1990b). It is not known that they possess, like the later Austronesian immigrants, genetic adaptations (e.g. Ovalocytosis) to endemic Malaria tropica or whether they have survived, as groups, despite high malaria child mortality, through individual premunisation effects brought about in the ones who survived by repeated infections. The mass of the peoples of the interior of New Guinea, however, have lived and still live above $1,600 \mathrm{~m}$. For the early dispersal of Papuan groups this must have been an important factor: they were trading a lowland habitat rich in protein but endangered by parasitic infections for a highland habitat precariously low in protein but with less fewer infectious diseases.

Ernst Büchi (1981) and Horst Jüptner (1983) of the German Research Team team, physical anthropologist and specialist for tropical medicine respectively, have both corroborated the primary impression that the Eipo (like their neighbours east and west) were surprisingly healthy. Indeed, they were, as mentioned, very powerful people, despite the then complete lack of modern medicine (Braun, 1996). Among the Eipo as in some other highland communities there was only one malnutrition problem: iodine deficiency goitre, often enormous in size, which led, in some valleys interestingly more so than in others (genetic effects?) to occasional 
cretinism in children whose mothers did not produce enough thyroid hormones during pregnancy (Schiefenhövel, 1982).

\section{THE EIPO IN THE CENTRE OF THE MEK REGION: UNTIL 1974 ONE OF THE LAST TRADITIONALLY LIVING GROUPS IN HIGHLAND NEW GUINEA}

Elsewhere, summaries of the culture of the Eipo have been published (Schiefenhövel, 1976, 1979, 1982, 1991), it will therefore suffice here to mention central elements of their traditions as they will serve as points of comparison with neighbouring groups so that, hopefully, a more general picture emerges which will facilitate the formulation of hypotheses concerning origin and dispersal of possibly prehistoric and of more recent ethnic groups which have managed to successfully settle in the rugged region of highland New Guinea and are descendants of the early immigrants who arrived at the shores of New Guinea so many tens of thousands of years ago.

The Eipo inhabit the valley of the upper Eipomek (formerly "Marijke" or " $X$ ) River which has, in the form of a magnificent waterfall, its headwaters at the northern edge of the central range in about $3,600 \mathrm{~m}$ altitude and rapidly flows northward, joining with other rivers and eventually reaching the Idenburgh/ Taritatu River, which further downstream becomes the mighty Mamberamo. The first airstrip was built by the German Research Team/GRT in the course of 12 months together with Tayiniyak, a Dani assistant from Ilu, and the local people. The new station was called Eipomek (mek, like ok in the Ok languages, is the term for water and river), according to the main river of the valley. This term has remained the name of the central Eipo settlements, situated approximately $140^{\circ}$ east and $4^{\circ} 26^{\prime}$ south. The name of the ethnic group is Eipo. From 1974 to 1976 the population of the upper Eipomek Valley, comprising of 6 villages, was about 800 persons. Roughly the same amount of people lived in the other villages of the Mek region north, south, east and west of the central range, so that the members of this ethno-linguistic group could be estimated to number approximately 10,000-15,000 persons at that time. Today, 2017, the Mek, unfortunately divided by a straight line separating the Star Mountain Regency from that of Yahukimo, probably number 50,000 or more inhabitants (Profil Kependudukan Provinsi Papua, 2015) - demographic growth, due to giving up warfare and preferential female infanticide, reduced age of menarche from 17 to 14 years, shorter post-partum coitus taboo and thereby shorter interchild intervals, and basic healthcare lowering infant and general mortality, is stupendous - and will create, sooner or later, problems.

Physical, geographic barriers (except the highest ranges of the Himalaya) have not generally impeded human dispersal (Schiefenhövel, 2014) as one can see from the fact that the Mek, exactly like the Ok in the east and 
the Yali or the Dani in the west, straddle the central cordillera, i.e. their cultures span right across this massive hurdle of steep and dangerous mountain passes in 3,500 - 3,700 $\mathrm{m}$ altitude and higher. The amazing athletic fitness of men and especially women was already mentioned, achieved with a nutrition deemed insufficient when judged from the standards laid down in western medical textbooks.

The social structure of the Eipo society and that of their neighbours in the Mek area was characterised by marked cultural sexual dichotomy: the worlds of women and men were seen as, in many respects, necessarily different, requiring different emic approaches to make society function. This is a classic Papuan topos, typical e.g. for the Sepik River cultures (possible ancestors of the highland societies, see below) and for the cultures of the south coast, both in the west (e.g. Asmat, Marind anim) and the east of the border with Papua New Guinea (Kiwai, Goaribari, Era, Purari and Toaripi cultures in Papua New Guinea). In contrast, the Austronesian societies in mainland and island New Guinea are often matrilineal and have a somewhat different (in our western perspective more modern) view of men and women and even feature, at least in some dances of the Trobrianders, a kind of unisex idea with men and women being dressed in similar skirts and dancing the same choreography (Schiefenhövel, 2004). Eipo and Mek dancing is, choreographically and symbolically, very different for men and women. Needless to say, there is a lot of good-spirited companionship between women and men, a lot of laughter, good cooperation in the daily garden work as well as passionate and often romantic love (Schiefenhövel, 2009). Physical contact, let alone erotic advances, between the sexes were strictly taboo in public; this is also a typical element of Papuan traditions in Melanesia (Schiefenhövel, 2001).

Mek boys and male juveniles went through a three-stage initiation process. The first and most important one is called kwit in Mek language; the Yali and Dani terms are wit, thus indicating an eastwest movement of an important religious institution as kwit is likely be the older, wit a derived term. Girls, as was the general sentiment, grow up to become perfectly normal women without any culturalreligious shaping: there was no public initiation for females. Yet, they had one or two houses per village strictly reserved for them: the women's house (bary' eik) for menstruation, birth, puerperal period, major disease... and conflict with their husbands. Interestingly, the women's house, built at the fringe of the village, does not seem to be a general highland Papuan institution (cp. Hampton, 1999) The male equivalent was the sacred men's house (yoek aik), usually situated in the centre of the village-a typical institution in many highland and even lowland (e.g. Sepik, Papuan Gulf) New Guinean societies (cp. Hays, 1991).

The "real" houses (dib eik) were 
the family huts in which the women, their children, often other relatives, also pigs, dogs and sometimes the husbands stayed. All houses except the bary eik, which was simple and had an earthen floor, were built on posts and had elevated floors. Proper roofs were round, though some had a rectangular shape; thatch made of pandanus leaves was used for ordinary houses, while sago leaves from far down the river, were reserved for some of the important men's houses. All Eipo houses had only one floor and small entrances-the latter a protection against sudden attack and also preventing heat loss. The inside housed sacred elements, e.g. the round fire place and its posts erected in a square, sacred string bags with skulls or other relics of ancestors hanging at the wall. The men's houses had the most powerful sacred elements. In the village of Munggona (today's Eipomek), a highly venerated sacred "digging stick" (kwemdina kama) was the most important of these objects; it was burned, together with other religiously meaningful objects, by members of the Unevangelized Mission after the earthquakes in 1976-a fact now deplored by the Eipo who have thus lost important ties to their ancient past.

A number of Eipo and Mek cultural markers were identical or at least similar to those found in other highland Papuan societies. Apart from the ones mentioned: penis gourds for men, skirts of reed or similar grass-like plants for women, male hunting, male armed intragroup fights and intergroup warfare (leading, among the Eipo, to a homicide rate of about 3-4 per 1,000 inhabitants per year, thus very high compared with modern western societies, Schiefenhövel, 2001), exocannibalism, bows made of black palm (Arecaceae) and non-poisoned, partly slightly barbed arrows, pigs (basam, Sus scrofa) and dogs (kam, Canis familiaris) as domesticated animals, use of cowrie, nassa and cymbium shells as well as teeth of pigs, dogs and marsupials plus feathers of birds of paradise (especially Paradisea minor) and other birds or fur of animals for body decoration, the everpresent string bag (aleng), stone adzes ya), digging sticks (kama) of various sizes as only gardening tool, garden mounds with mulching, fallow periods of 15 years and more, Cordyline terminalis as sacred plants identifying special places, lack of pottery, steaming food for larger groups of family or visitors in big earth ovens (fito, Bahasa Indonesia: bakar batu). But the Eipo culture also exhibited a number of quite stunning dissimilarities vis-à-vis the neighbouring societies.

In many mountain Ok cultures, east of the Mek, carved and painted shields were used in warfare (cp. Jorgensen, 1991) The first fighter in a single file line carried this protection, the partly anthropomorphic reliefs of which can be interpreted as awe inspiring, threatening apotropaic images. When a war shield (askom in the Ok language spoken in and around Bolivip/Bolibip, Papua New Guinea) had been successful in protecting the warriors it was elevated to a sacred object and hence kept in 
the men's house (yolam), together with hundreds of pig jaws, giant taro tubers and other socially and religiously meaningful objects. The inhabitants of the Inmak Valley around Kosarek, also speaking, like the Eipo, a Mek language, surprisingly also some Yali villages west of Kosarek, had similar carved and painted shields, yet not used in warfare. They were named kelabi in the language of the In culture and language group around Kosarek (Heeschen, 1992), sabal hä in Yali (Zöllner, 1977) and represented ancestral spirit women: the In language word kelabo corresponds to the Eipo word kelapo = woman; the Yali term sabal hä means "old woman". These shields were also kept in the sacred men's houses and played a central role in the ceremonies thought necessary to ensure the fertility of the gardens and the wellbeing of humans. This is an interesting parallel to Afek, the central female figure of Ok religions (see below).

The Eipo proper did not have any shields, but the idea of a sacred wooden, painted object was present in a very inconspicuous, small, very simple piece of wood which was used in sacred ceremonies taking place at the lower end of the notched beam leading to the entrance of the men's house. The function was sacred, i.e. similar as in the shields east and west of Eipomek, but the form was surprisingly different. The term kelabye is, etymologically, the same as in the in language, inferring a female being. Sometimes this very modest, ad hoc produced object was called kelabye lakasu or kelabye lakaswe, meaning the inner core of the kelabye, i.e. of the sacred woman. In the Famek Valley, just west of the Eipomek Valley (these two groups were hereditary enemies since time immemorial) Wolfgang Nelke was given kelabi shields. It seems that this was a cultural import from the western Mek region. Why the geographic centre of the Mek culture, the Eipomek Valley, should have lost or never had the concept of large, impressive carved shields is unexplained at the moment. One kelabi presented by W. Nelke to the ethnographic Loka Budaya Museum of Universitas Cenderawasih in JayapuraAbepura is the single Mek object still present in this museum; all the other, numerous objects of the material culture of the Eipo and their neighbours, several complete collections, which were handed over in 1975 and 1976 seem to have, unfortunately, disappeared 6 .

Both Ok and Yali cultures had carved and paint-decorated planks of the men's houses. Again, the Eipo culture is a kind of ethnological vacuum in this respect. The same is true for the missing drums. Singing and dancing in the western Mek area around Kosarek, in the Ok, In and Yali villages was and is accompanied by vivid drum beating. The Eipo men have a sophisticated way of pentatonic polyphonic singing and rhythmic inspiratory whistling when they dance, while the women emit very high inspiratory shrill sounds during their very different, much more elegant 
way of dancing, accompanying the male singing with a rhythmic rustle of their especially thick reed-skirts put on for the occasion, but: no drums! This is quite strange, because the drum is the classic music instrument in basically all Papuan and Austronesian societies. The Eipo, as their neighbours east and west, do have the mouth harp for making occasional, individual music, which is not normally directed at an audience. Also missing in Eipomek are bamboo pipes for smoking, another rather typical element of Papuan material culture; the Eipo smoked small cigars of local tobacco (saboka, the term may still reflect its Amerindian-lberian origin!) rolled in leaves.

One particular body decoration, present in various shapes in the Miku culture of the Upper Digul region (cp. photograph of P. Wirz, published in Chauvet, 1930) as well as in the adjacent Jee-anim/Marind-anim culture (Wirz, 1925) consists of strands of fibres either woven into the hair or put on the head of men and hanging down the back. It is very elaborately evolved in the Ok culture of the Faiwol near Bolivip/Bolbip, where it is called kamil. The groups around Oksibil called it mafum and made a similarly complex thick, round ornament of rattan, other fibres, leaves, clay and ochre (Brongersma and Venema, 1960). The thick bottom part is "female"; on top is a much smaller and slimmer, lancetlike part, which represents the penis. In the Telefolmin area a less sophisticated but large, and also female-male head ornament was worn by the men (photo in Craig and Hyndman, 1990). The Ngalum/Nalum, the westernmost Ok society in the Star Mountains Regency, so empathically described by Sibelle Hylkema (1974) also had this unusual, striking piece of male body decoration. In the culture of the Eipo, it is just the smaller "male" piece, which has survived, its name is mum, etymologically derived from mafum, which must be the older term. It is also seen as a penis symbol and if, e.g. during a nightly dance, a woman touches a man's mum, this is a clear invitation to have sex with her. Eipo men usually wear it at official dances or when they want to attract the eyes of a woman, i.e. as bachelors. The Yali had three types of this specific back decoration, not twisted into the hair (Zöllner, 1977). Most interesting is that their version is closer to the Ok version, as it also consists of two pieces. Again, the Eipo culture has a partial vacuum here: is the "female" part lost due to cultural impoverishment or was the "female" part of the mafum primarily not introduced into their material inventory of the Eipo?

\section{STONE ADZES FROM THE HEIME VALLEY: AN UNBROKEN PALAEOLITHIC TRADITION}

Throughout the "Ok-Mek Minisphere" (Swadling, 1983) and even farther away in the adjacent regions of the Yali and Dani in the west and the Papua New Guinea Mountain Ok (even into the Telefomin area) and Lowland OK in the east, as well as to the northern 
side of the mountain range towards the Sobger/ldenburgh/ Mamberamo River system, the Mek-type of stone adze (ya) is found: produced at the quarries in the upper Heime/Mumyeme Valley near the airstrip of Langda (Schiefenhövel, 2015), almost exactly south of the Eipomek River, and near the airstrip of Sumtamon east of Langda (Petrequin, 1990-1992). The geological material for these adze blades is Andesite (Helmcke, 1978), a material very suitable to be relatively easily knapped and ground into very well functioning, durable adzes. There are only a few quarries in the area between the Ok in the east and the Dani in the west (Swadling, 1983; Petrequin and Petrequin, 1990-1992, 2006): a) Yeleme/Jeleme in the Nogolo basin in the western Dani region, about $150 \mathrm{~km}$ northwest of Wamena, the highland capital in the Balim/Baliem River Valley; this stone is darker than the stones from the upper Heime/Mumyeme and Sumtamon quarries and is usually fitted longitudinally, as an axe, into holes of simple, massive handles; these axes are traded widely, even down to the south coast; b) Tagi in the area of the Grand Valley Dani; c) Mumyeme and Sumtamon (see above). Raw adze blades produced from this Andesite rock are, as mentioned, very suitable to be turned into effective, long-lasting adzes which are polished by the "end user" and then sophistically hafted as adze; as mentioned this type of adze is traded to regions far outside the Mek area; d) a much less researched and possible not very important quarry at the upper Red Digul River. Sneep (2005) reflects on the temporal and functional connection of stone axes and the begin of agriculture and it is indeed an interesting question whether stone adzes and axes as specialised lithic tools were coming into use with the new technique of horticulture. A fragment of a polished stone adze or axe has, however, been found in an Australian site dated to about 44,000 - 49,000 PB (Hiscock et. al., 2016), this is very much earlier than the begin of agriculture in New Guinea (about $8,000 \mathrm{BP}$ ) and, additionally, the Australina Aborigines never went beyond hunting-gathering in the predominant subsistence strategies.

P. Petrequin and A. M. Petrequin (1990-1992) write that the use of the stone axes and adzes has stopped some decades ago. This is correct concerning their everyday use as wood cutting tools. The fascinating fact is that stone adze blades from the Mumyeme and possibly of the Sumtamon quarry, are still produced and used today (Schiefenhövel, 2015), because they represent a traditional currency for bride price payments and payments in the course of customary compensation for inflicted damage. The professionals, extremely knowledgeable and skilled knappers (the only ones who have a specialised function in the society and spend a lot of time in this "job") are still producing the astounding blanks. The first step is to apply fire to produce cracks in large Andesite rocks, and then large, heavy round boulders are used to break off portions of the fire-split rocks and to 
break them further into smaller material with can be hand-held. Then the job of the knappers sets in: extraordinarily finetuned movements to turn a stone into a beautiful blade (cf. Stout, 2002). It is like watching a palaeolithic contemporary performing his artful task.

\section{RELIGION}

Besides traditional materials and techniques which are, as it were, frozen cultural inventions, persisting, in prehistoric context, for often very long times because they represented the best technological solution available (like the production of specific stone adze blades, their grinding and polishing, up to the very effective and protective way of hafting), religious traditions promise to be a window into the past. Religious beliefs, traditions and their defence against "non-believers" are a powerful well from which ethnic identity is fostered (cp. Schiefenhövel and Voland, 2009). Humans cling to their religions until a new, for some reason more attractive one appears and is accepted. In palaeolithic and neolithic times the situation in highland New Guinea most probably was, in the same way, characterised by religious conservatism.

It is, therefore, an interesting exercise to compare religious traditions of Papuan peoples who have been rather isolated for so many tens of thousands of years until the first Austronesians arrived. The decisive religious marker of the Ok region is the belief in Afek, a spirit woman who was believed to have, at the beginning of humankind, played a most important role as shaper and transformer of things. Her figure has characteristics of a superhuman trickster, so common in many animist belief systems, on the other hand is her humanness, her femaleness striking. She was the central figure of the religious cults in all Ok country (Brumbaugh, 2005) - except the Ngalum/Nalum.

Sibbele Hylkema, in his very insightful account of Ngalum/Nalum life around Abmisibil (1974), Star Mountains Regency of Papua Province, does not mention Afek at all, he names Seramki as the creator figure. Also Jan Pouwer (1964), ethnologist of the Dutch 1959 Star Mountains expedition to the Ok west of the international border does not mention the Afek cult, which was and to a certain degree actually still is today, so powerful among the Papua New Guinea Ok. Anton Ploeg (2013) refers to this fact and speculates that both authors may have missed the spirit woman because a) the cult did actually not reach the OK cultures in the west, which, or because b) of the secrecy of the cult (Pouwer, during his field study in the framework of the Dutch Sterrengebergte Expedition, spent limited time in Denmatta north of Oksibil, but S. Hylkema, on the other hand, gained, as mentioned very solid insight into the lives and minds of the Ngalum/ Nalum during the many years he lived with them) or because c) the figure of Afek was transformed into supernatural entities typical for the western Ok. 
In any way, it is surprising that the so powerful Afek-myth, uniting all the different other Ok groups east of the international border, is not present in the Ngalum/Nalum-Ok. At Set Bip near Serambakon village west of Oksibil is a sacred place where, according to local tradition, Atenki, the creator spirit, created all humans and threw them into the air so that they would depart into the regions still typical for their clans and groups. Whether Seramki mentioned by Hylkema (1974) as the father of all humans is the same personage as Atenki or represents another creator spirit is uncertain at the moment.

In the Mek culture, a female spiritdeity is definitely missing as well. In their belief, it was primarily Yaleenye who, as a creator and (in the term of Brumbaugh, 2005) "transformer", had the most decisive impact on the life of early humans and who set most traditions in motion (Schiefenhövel, 1976; Heeschen, 1990). It is very interesting that the literal translation of Yaleenye is "The one who Comes/ Came from the East". Mek religion, thereby, postulates a deitylike being from the east as the one who started all things, formed the valleys with his feet, smaller rivers with his hands and who impregnated female animals and animal-like humans to bear his offspring. He was a big rover, never stayed long in one place, and went from east to west, to both sides of the central mountains in a seemingly erratic course. As Volker Heeschen writes (1994) the narrative of his movements, his travels, is, at the same time, an account of what was created or transformed - deictic concepts as the core of oral history. Whether one can infer actual movements of populations from mythical accounts (Heeschen, 1994) like that featuring Yaleenye or other sacred ancestors, remains an open question. The Mek culture seems to be the origin of this deity.

Zöllner (1977) writes that the central figure of Yali mythology is the male spirit Jeli who is killed and thereby sparks off important elements of life, thus acting involuntarily through his death. The Yali are aware of the fact that his name means "Eastern". One can therefore safely assume that Yaleenye and Jeli (Yeli in modern orthography) are very similar religious concepts. The Yali had a number of female figures, who were believed to have played a major role in the beginning of humankind (Zöllner, 1977) one of them was Sabal Hä (lit. old woman; see description of sacred shields, above). The same is true, albeit to a probably slightly lesser degree, for the Eipo, where the Kwaning Fatane Gil, a spirit woman who is always hungry (the translation of her name), steals food from real people and also enters their bodies, thereby making people fall ill and die by being eaten from inside. Another religiously important female figure is Ise Gil, the Spirit Woman who can move underground through the mountains, and can also cause harm and death. These figures are different from Yaleenye, because religious Eipo tradition says that they have survived from ancestral times 
until today, whereas the mighty creatortransformer is not living any more. It is obvious, then, that the very powerful female-mother figure of Afek does not have real counterparts further west of the Ngalum/Nalum, also not among the Yali. The Mek concept of the Yaleenye deity, on the other hand, has influenced Yali religion; this is in contrast to the fact (see above) that the central Mek culture is void of some important elements of the typical Highland Papuan cultures.

For the cultures in the Star Mountains Regency, the formerly snowcapped Abom (approximately 4,700 $\mathrm{m}$ high Mount Juliana, today Gunung Mandala, cp. Brongersma and Venema, 1960 ), is a highly sacred peak. People from the Ngalum/Nalum $O k$ around Oksibil to the westernmost Mek around Kosarek in the valley of the In River were united in the believe that the male Abom mountain had sexual intercourse with the female Ablim/Aplim/Lime mountain (approximately 4,500 m high, $22.5 \mathrm{~km}$ straight line north-west-west of Abom) and thus gave rise to the first human beings.

Other mountains, like the Binal (approximately 4,100 m high, south of the Eipomek Valley) are also important for the mythological accounts of early human life, especially their origin, but none can match Abom and Aplim. It is interesting that the Yali around Angguruk have the belief that an early, much taller generation of humans lived in their land who were all wiped out by a gigantic earthquake. Skulls and long bones, which the Yali find when they make new gardens, are attributed to this natural disaster (Zöllner, pers. information 2013). These bones have not been anthropometrically measured yet, so it is not known whether a taller population once lived in the Yali area or not. The legend as such is not likely an account of reality, as even the most powerful earthquake would not kill all humans in a given area; this can be extrapolated by the two massive earthquakes in 1976 in Mek region. The extinct "giants" are called Limlim in Yali language, this probably indicates a connection to the Lim/Ablim/Aplim peak which has, in contrast to more roundish Gunung Mandala/Abom, a rather characteristic limestone top and is easily recognisable from far away. This religious tradition of the Yali plus the aforementioned term for the first male initiation suggest a dispersal of religious ideas (and of early highland people?) from east to west.

\section{LANGUAGE}

Regarding the highlands of New Guinea, a good deal of work has been done to document the local languages (Figure 1). In most cases this difficult task has been undertaken by missionaries (for the region in focus here: e.g. Drabbe 1950 , for Awyu, he also wrote dictionaries of other languages in West-New Guinea, Hylkema 1974 for Ngalum/Nalum, Louwerse 1978 a, 1978 b, 1988 for Una, a Mek language, and Zöllner undated, for Yali) or, more commonly, by members 
of the Summer Institute of Linguistics, an institution giving support to studies in hitherto un-contacted or little contacted areas with the final aim to facilitate translations of the bible into the local languages (e.g. Bromley 1967 for Dani), or by scientists (e.g. Healey 1964, for Telefomin; Heeschen and Schiefenhövel 1983, for Eipo/Mek; Heeschen 1992, for the "Yale", the language of the Mek speaking inhabitants of the Inmak River around Kosarek).

The diverse linguistic and cultural situation in Highland New Guinea and generally in Melanesia has traditionally attracted specialists. In the field of linguistics a large corpus of data and convincing meta-analyses have been presented (cf. Wurm 1960, 1975; McElhanon and Voorhoeve, 1970; the linguists with chapters in Pawley et al. 2005: A. Pawley, M. Ross, W. Foley, B. Voorhoeve, D. Donohue and M. Crowther, G. Reesink, who summarise present-day knowledge and theory). The hypothesis that most of the Papuan (i.e. nonAustronesian) languages of mainland New Guinea, including several islands in the west and east, are belonging to one large language family, termed "TransNew-Guinea-Phylum” (Wurm, 1960), "Trans-New-Guinea I" (McElhanon and Voorhoeve, 1970), "Trans-New-Guinea II" (Wurm, 1975), "Trans-New-Guinea III" (Pawley, 2005) and "Trans-New-Guinea Subgroups" (Ross, 2005), has been verified by studies; some differences of opinion concerning which grouping best reflects the linguistic mosaic remain.
A few linguistic conclusions with regard to the question of how early Papuans dispersed are of particular interest:

a) Papuan languages included in all modern groupings are spoken from the islands of Timor and neighbouring Alor, as well as on Tidore, Ternate and North-East Halmahera, west of the New Guinea mainland, throughout large sections of the island from the "Birds Head" right to the "Tail" of the "Bird" in Papua New Guinea. Interesting are the "language isolates", which could, but must not, represent a possibly earlier or later period of immigration than the rest. It is also possible that their relationship to the Trans-New-Guinea grouping will be discovered when more research data become available. The fact that some of the islands west of New Guinea (e.g. Alor and Tidore) have some Papuan linguistic innovations in the field of pronouns (Ross, 2005), is particularly important in light of possible migration or dispersal routes. These regions could, indeed, be an ancient centre of dispersal reflecting the fact that the Proto-Papuan immigrants came through there and remained for a considerable time.

b) Do the related languages of the TransNew-Guinea groups represent an old dialect continuum (Ross, 2005)? In my view, this is the most parsimonious explanation for the relatedness of the 
Papuan languages; it would speak for an immigration of one or a few groups of Proto-Papuan speakers around the time of their arrival at the shores of New Guinea 50,000 or 40,000 BP or earlier. Language and cultureformation can be seen as a quasiDarwinian process (cp. Oudeyer and Kaplan, 2007) lexical and grammatical changes ("mutations") lead, via pseudospeciation (Erikson, 1966) to the formation of new dialects, later of languages and socio-culturally divers institutions: New Guinea with its striking cultural diversity, is a specifically striking example of this process.

c) Why is the linguistic scene in much of highland and south coast Papua New Guinea more scattered than in the Province of Papua? Does this reflect a dispersal from Papuan groups at the north coast of PNG up the Sepik River (Swadling, 1983) to the highlands in eastern New Guinea, to the south coast and then a perhaps, in a slower process, to the west and south-west? It is indeed striking that the geographic size and the number of speakers per language group in the Province of Papua is much bigger than that in Papua New Guinea. Some of the cultural characteristics described above corroborate this general eastwest movement.

\section{POSSIBLE ORIGINS OF THE MEK}

It was shown above that the central Mek culture misses a number of items which are important elements in the surrounding Papuan cultures: drums, carved and painted fighting shields, carved and painted sacred shields representing female creator figures, carved and painted boards of the men's houses, bamboo pipes for smoking. A possible answer for the Eipo missing these cultural markers could be that they have immigrated, at some stage of long Papuan history, into the area where they now live. As they do not share the missing elements, it is not likely that they have come from east or west, because these elements are present there. They might have come either from the south, the Korowai or another language group of the Awyu-Dumut language family (Ross, 2005), following the course of one of the big southern rivers leading to the central range (e.g. the Heime/Steenboom River or the Ok Cop/Digul River). If one takes the perspective that important goods, like marine shells, most likely came this way (Swadling, 1983) then this route is more probable than an immigration from the north, via the Idenburgh and one of its tributary systems, e.g. the Ba/Kloof or the Borme-Bime-Tanime-EipomekNalcemak system, all draining the northern slope of the central cordillera. In light of a possible linguistic relatedness of the Ok languages and Awyu-Dumut (Ross, 2005) and the fact that there are some important cognates in Ngalum/ 
Nalum-Ok and Mek (Hylkema undated, Heeschen and Schiefenhövel, 1983) it is reasonable to hypothesize that the Mek languages are also connected to this large linguistic family south of the central cordillera. This would, if confirmed e.g. by genetic studies, point to a migration of the Mek into the central highlands originally from the south coast of WestNew Guinea, not as proposed by P. Swadling (1983) the other way round, i.e. via the Sepik fro East New Guinea - a new twist in the most likely very complex dispersal pattern of Papuan peoples.

A problem for the hypothesis presented here is the question why the early Mek did not take the drum with them when they moved from the south coast to their today's homeland. The fact that they do not use bamboo pipes for smoking could partly be explained by the fact that large-diameter bamboo does not grow in the high altitude region of the central Mek; bamboo tubes of that size are, however, traded in and used as container for drinking water. Another problem for the hypothesised southnorth migration is Yaleeny, the creator spirit; his name signifies the East as his origin. What does this mean and how did the female Afek deity of most of the Ok turn into the male Mek deity of Yaleenye?

\section{AUSTRONESIAN INFLUENCES}

As early as the end of the $19^{\text {th }}$ century linguists discovered (Kern, 1886; Schmidt 1899 a, 1899 b) that the languages of the West-Pacific, including Taiwan, the Philippines, Indonesia,
Malaysia, Melanesia, Micronesia and Polynesia belonged to one extraordinarily large family of languages, which Wilhelm Schmidt, a German catholic priests, who became a very influential ethnologist and linguist and founder of the famous journal "Anthropos" called Austronesian, from Latin auster, southwind, southerly (cp. australis, southern) and Greek nesos, island. Otto Dempwolf continued this line of research $(1927,1929,1931)$ and postulated, in a similar way as had been successfully used for the IndoEuropean languages, a common ProtoAustronesian language as origin of all other languages belonging to this family. This early research, including that of Dyen (1965) and other authors inspired by Dempwolff, opened the way for contemporary studies on Austronesian languages, cultures and history, yet is often forgotten. Robert Heine-Geldern (1932) constructed, on the basis of stone adze morphology and other aspects of material culture, a similar link connecting all Austronesian languages and cultures from southern China to Polynesia. Today, we know, that the inhabitants of a very large area of the world, from Taiwan to Micronesia, to Polynesia including Hawaii, Easter Island, Tahiti and New Zealand, to Melanesia, to Indonesia, the Philippines, Malaysia and Madagascar belong to the Austronesian family of languages and cultures which have been very influential in the history of the Pacific and beyond.

Asouthern Chinese or, more often, Taiwanese origin of the Austronesians 
(Bellwood 1978, Bellwood et al. 1995, Lipson et al. 2014, Xu et al. 2012, Ko et al. 2014 and other authors, see below, 3.10 ) is contrasted to the generally less favoured, but also possible NusantaoHypothesis, put forward by Solheim (1984) which assumes that members of a pre-existing population of seafaring people in the west of the Indonesian archipelago were the ancestors of what is called Austronesian peoples today. The "Austronesian Diaspora" in presentday Indonesia is the subject of a number of publications by archaeologists and anthropologists (cp. Simanuntjak 2004, 2011; Mahmud et al. 2011) and, indeed, once this population entered the stage of the archipelagos of the West Pacific it initiated great changes, introducing new technologies, like very efficient sailing boats and ways of navigation, new social structures with often heritable male chiefs and matrilinearity (not to be confounded with matriarchy), probably pottery and most likely the advent of two "classic" domesticated animals of Melanesia, the dog (Canis familiaris) and the pig (surprisingly Sus scrofa and not some Asian or Southeast Asian domesticate, cp. Schiefenhövel, 2014). The arrival of members of the Austronesian population via the islands of the Philippines and Eastern Indonesia to the Moluccas and the western parts of New Guinea must have made a great impact on the native Papuans who dwelled at the coast and on the islands off shore, on their economy, their social structure and their technologies (like pottery), perhaps also with regard to religious traditions, even though this is very little researched. Today, some areas of speakers of Austronesian languages are found at the north coast of Tanah Papua and on the adjacent islands (Lewis, 2009). It is very likely that the Austronesians were the first to introduce long distance trade and thereby connected the isolated coasts and islands of New Guinea to the Moluccas and other regions and cultures of todays Indonesia and the Philippines, indirectly even to China. A small bronze object of pre-European origin has been found at the Sasi site on Lou Island in the archipelago around Manus far north off the coast of Papua New Guinea (Ambrose, 1988). This is quite an astounding find and demonstrates that the Austronesian sea travel and trade connections covered a very wide network, also to the East; in this case over a distance of about 2,000 kilometers open sea travel.

Surprising is that the beads and necklaces typical for the north coast of Papua and possibly connected to Austronesian and/or later to Chinese traders in exchange for birds of paradise, teripang/trepang or sea cucumbers (edible holothurians, plentiful in the shallow seas of the West Pacific and, since millenia, very much sought after by the Chinese for their culinary and purported aphrodisiac properties, Schwerdtner Manez dan Ferse, 2010) as well other New Guinean products, have not penetrated further inland than Lake Sentani (Petrequin and Petrequin, 
2006). In other words, this new set of most precious valuables and other innovations brought by the Austronesians and later traders, remained en vogue only in a limited region, i.e. on the islands and on some coastal stretches. On the other hand, cowrie, Nassarius, Cymbium and other shells found their way into distant inland Papuan cultures like that of the Ok and Mek, possibly from the south coast and via exclusively Papuan trade networks which were characterised by a small scale exchange of goods between neighbours. Yet, likely Austronesians imports like the pig and the dog made it right into the most remote valleys of the interior and became essential parts of the lives of Papuans all over New Guinea.

\section{POPULATIONS GENETICS OF AUSTRONESIAN AND PAPUAN PEOPLES}

Kirk (1966, 1982, 1992), Hill and Serjeantson (1989), Attenborough and the numerous other authors in the volume edited by Pawley et al. (2005) have given state of the art summaries of the available data and their interpretations concerning research in the field of Melanesian population genetics, which has, since the times when blood groups and HLA-markers were investigated, advanced with amazing pace and precision. The study of Cavalli-Szorfa et al. (1994) showed the power of a doublepronged approach, i.e. using modern genetics and linguistics, to understand population patterns - a very reasonable research strategy. One problem is how well defined the formerly collected blood samples, mouth swabs or collected hair actually are. With this in mind the groups around Lutz Roewer and Marion Nagy of Humboldt University, Berlin, and Manfred Kayser from Rotterdam University have identified, for the study of Austronesian populations in Milne Bay and Manus Province of Papua New Guinea (Nagy et al. 1997, Zimdahl et al. 1999, Kayser et al. 2000, 2003, 2006, 2008), each DNA donor to the grandparents and the villages where they have lived. This sampling method safeguards against overlooking genetic admixtures, which would otherwise lead to false interpretations. Attenborough (2005) and Harley et al. (2005) address the same issue.

The Austronesian peoples have received a large share of attention by population geneticists (e.g. Abdulla et al. 2009), Soares et al. 2011, 2016, Xu et al. 2012, Denham and Donahue 2012, Brandão et al. 2016), partly because the settlement of the vast Pacific Ocean is such an incredible human feat and because linguistic and archaeological studies had pointed to an allegedly very fast process of immigration from Asia to the Polynesian Islands, culminating in the "Express Train to Polynesia" hypothesis (Bellwood, 1978). Kayser and colleagues have been able to show, that it was indeed a "Slow Boat" process (Kayser et al., 2006): Austronesian newcomers picking up many genes from the autochthonous Papuans, probably in western New Guinea, and, as new 
genetic mixture, moved on to the east and then southeast. It is very interesting that the Asian women have obviously preferred the virile Papuan men: the Y-chromosome signature of the Asian men is rather weak in the Austronesian populations of the Pacific (Kayser et al. 2003). This research team has also been able to demonstrate that patrilineal descendence structures and virilocality so typical for Papuan populations, show up in the genetic data (Kayser et al. 2000). The molecular genetic study of Papuan peoples has, as other anthropological and archaeological research, mainly taken place in Papua New Guinea. Hopes are that the Provinces of Papua and West Papua can be included in international research to understand the patterns of dispersal and settlement of the amazingly old Papuan and the more recent Austronesian populations in New Guinea.

Main et al. (2005) interpret their genetic research results as proof that there were probably four different waves of Papuan speaking immigrants before the Austronesians arrived from Asia and that the highlanders belong to the earlier, whereas the peoples of the northern fringe and the Sepik belong to a later wave of migration. According to them, the peoples of the Southern Highland in Papua New Guinea are a separate group. They did not find Austronesian admixture in the genomes of peoples living in the interior of the Bismarck Archipelago, which was settled by Papuans long before the Austronesian sailing-specialists arrived. Easteal et al. (2005) argue that the pattern of mtDNA radiation in New Guinea can most parsimoniously be explained as the effect of the island originally being colonised by only a small number of people.

Harley et al. (2005) interpret their molecular genetic data from some Papuan groups in the interior of Papua New Guinea as showing segregating effects of the high central cordillera. In their study, the genes of inhabitants of the village of Busilmin, who live at the northern side of the Star Mountains in PNG, and the ones of the village of Bultem at the southern side, are quite different. No genetic study has yet been carried out in the Mek area, but we are sure that one would be able to demonstrate a quite opposite effect: historically and currently there is a very close marriage and trade relationship between the Eipo in the north and the Una inhabitants of the villages in the Upper Heime Valley in the south of the central cordillera despite the high mountains with passes of $3,700 \mathrm{~m}$ altitude separating them. The direct western neighbours of the Eipo, easily in reach for marriage, are the inhabitants of the Famek Valley; yet the two groups were hereditary enemies and only one known marriage and one love affair (which did not result in offspring) were observed from 1974 to 1980 . After that time the pax christiana spread in the region and warfare was abandoned, leading to a now unimpeded contact and marriages across the old barrier. As mentioned, we argue that it is not the high 
mountains or other geographic borders, but pseudospeciation (Erikson, 1966), i.e. cultural separation brought about by biopsychosocial factors, which lead to strong identification with and loyalty to the own group on the one and to ideological separation, and serious warfare on the other side (Schiefenhövel, 2001). This process is likely to have been the main motor, which has brought about typical New Guinean cultural diversity.

As mentioned above, one puzzling outcome of genetic studies is that there are very little, if any, commonalities between the genetic make-up of Papuans and Australians (Stoneking and Wilson, 1989; van Dijk 2005), despite the fact that they must have arrived, through the then available land bridges, around the same time, (about 40,00050,000 BP or earlier) and that the Sahul land connection, which had persisted for several tens of thousands of years of human settlements, between the Fly River region and Northern Australia later became a relatively easily crossed sea connection via the Torres Straight Islands.

\section{CONCLUSION}

Many questions regarding the earliest migration of Papuan peoples into the highlands of New Guinea are unresolved. How quickly after their arrival at least $40,000-50,000 \mathrm{BP}$ at the shores of the big island did this happen? Did the Ice Age with its low temperatures, snow and glaciers on the high mountains keep the mobile groups of hunters and gatherers out of the higher ranges or were snow and frozen ground no insurmountable hurdle for them? Just a few decades ago the people of the Star Mountains would walk, barefoot and with no protective clothing, into altitudes above $4,000 \mathrm{~m}$ sea level, where snow and ice are not uncommon and stay there to snare small marsupials. Humans can perform these almost superhuman tasks. It is possible that the earliest inhabitants of the highlands eradicated, through hunting, some species of now extinct very large marsupial animals as long as 30,000 years ago (Hope and Haberle, 2005).

As mentioned above, archaeological researchers conducting field work in Papua New Guinea have found signs of human habitation more than 40,000 BP in caves at altitudes of $2,000 \mathrm{~m}$ and higher. No archaeological excavations and datings have been carried out so far in the highland of Papua Province, but is seems more than likely that the mountains and caves there are holding similarly interesting remains. Modern archaeological research, including ethnoarchaeology, anthropology and population genetics, will help to understand the chronology of the peopling of the interior of Papua, the possible routes, which the early migrants have taken as well as the historic and cultural connection between them.

The evolution of the enormous cultural and linguistic diversity so typical for Melanesia and the fact that ethnolinguistic diversity is greater in 
Papua New Guinea than in Tanah Papua, is, up to now, insufficiently explained. Why are there so many different ethnic groups in Mainland and Island New Guinea? No doubt, the long time people have lived there has played a role. As mentioned above, languages evolve in a similar way as biological species, through mutation and radiation and the longer this process goes on, the more languages will arise. The question is whether this explanation plus the assumed separating effect of the mostly very rugged interior of New Guinea is sufficient to account for the magnitude of (depending on the method of counting) 1,000 or more ethnolinguistic groups, of which many small ones have died out already.

Until recently, the Papuan men belonged to the most aggressive warriors worldwide. Homicide rates among the Eipo were between 3-10 persons killed per 1,000 inhabitants per year, or expressed in a different way: every 4th or 3rd man would have died from violence; in other ethnic groups homicide rates were even higher. In Tanah Papua the pax christiana has changed this dramatically: in the Mek region, homicide is a very rare event these days. Yet, for the longest periods of Papuan history this martial attitude was probably a decisive factor bringing about small ethnic groups with a high degree of identification and loyalty, who defended their territory and their way of life, their language, their music, their body decoration, dance, religion and so forth against others, usually their direct neighbours.

This process of pseudospeciation (Erikson, 1966) was probably nowhere more pronounced than in the Papuan societies of the past. Archaeological research, especially on durable parts of body ornaments, which will have survived long periods of time in the often wet tropical soil and now wait to be excavated, will shed light on the scale and history of this process. Beads and other ornaments made of shells from the far-away sea (probably in the south), of teeth, bone and stone are a particularly important element of this research. The inhabitants of the Star Mountains still keep the ornaments of their ancestors, which can thus be studied ethnoarchaeologically. These elements of body decoration represent extracorporeal ornamentation, which, unlike lithic tools, is free of functional pressure and can thus represent and signal belonging to specific ethnic groups (Vanhaeren and d'Errico, 2006; Vanhaeren, 2010). A recent study (Antunes 2015, Antunes et al. 2015) has shown that environmental factors (altitude, temperature, rainfall, geological conditions, vegetation...) can, in by far the most cases, not predict the presence of specific ethnolinguistic groups; the highlands of Papua and Papua New Guinea, represent a very similar ecology but are home to many well-defined groups with very different languages and cultures. As mentioned above, the appearance of cultures can 
probably best be explained as the effect of biopsychosocial drivers which lead to pseudospeciation (Erikson, 1966) - a process which can be observed even in our modern urban environments where subgroups, "sub-cultures", are constantly forming; they create smaller units of people who feel, in the environment of the mass society, united by the same kind of behaviour, slang, music, dress and ideological, quasi-religious convictions (Maffesoli, 1996).

It is usually assumed that "prehistory" was replaced by "history" many thousand years ago when writing, metal and other hitherto unknown technologies were invented. In parts of the highlands of Tanah Papua, however, prehistory reached right into our days. The neolithic method of producing stone adzes by knapping is actually still practiced today by some groups in the Mek region, probably the only such place in the world where these adzes are not only produced, but also used in ceremonial exchange. The Eipo in the centre of the Mek culture and language group had, when interdisciplinary research there began in 1974, a mixed neolithic subsistence strategy consisting of horticulture as well as gathering and hunting, all tools were made of nonmetallic materials, there was no firsthand knowledge of the world outside the small mountain areas beyond a distance of three days walking. Cultural change has happened very fast. Many Eipo have received university education and many are participating in the political life of their regency. Yet, for archaeological and ethnoarchaeological research the Star Mountains are still a kind of undiscovered paradise as only very limited archaeological field work has ever been conducted there.

The Ok and the Mek are eager to learn about their origin and their distant past. They have understood that archaeology and related sciences, including modern DNA research, are the way to achieve this goal. The government of the Star Mountains Regency is also very supportive of field studies there. Modern research in that region will contribute to a better understanding of some of the earliest phases of migration of our own species Homo sapiens into Mainland New Guinea at the eastern most fringe of the then accessible world. Such research and its valorisation through the media, schools and universities will help the Papuan peoples to value their cultures, which belong to the most ancient ones of our globe.

\section{ancient ones of our globe.}

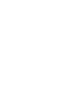




\section{REFERENCES}

Abdulla MA, et al. 2009. HUGO Pan-Asian SNP Consortium; Indian Genome Variation Consortium. Mapping human genetic diversity in Asia. Science 326:1541-1545.

Ambrose, W. R. 1988. An early bronze artefact from Papua New Guinea. Antiquity 62: 483-491.

Antunes, N. 2015. Application d'algorithmes prédictifs à l'identification de niches écoculturelles des populations du passé: approche ethnoarchéologique. Doctoral Thesis, University of Bordeaux.

Antunes, N., Vanhaeren, M., Schiefenhövel, W., Rigaud, S., Banks, W., d'Errico, F. 2015. Ethnolinguistic niche modelling: The case of New Guinea. The role of culture in early expansions of humans, July 13th - 17th, ROCEEH, Frankfurt. (Poster).

Attenborough, A. 2005. Introduction to the chapters on biological anthropology and population genetics: In: Pawley, A., Attenborough, R., Golson, J. and Hide, R. (Eds.), Papuan Pasts: cultural, linguistic and biological histories of Papuanspeaking peoples. Pacific Linguistics. Research School of Pacific and Asian Studies. The Australian National University, pp. 673-691.

Balai Arkeologi Papua. 2017. Lukisan Megalitik Tutari. Buku Panduan Muatan Lokal, Kelas VII SMP Semester II. Kementerian Pendidikan dan Kebudayaan.

Bellwood, P. S. 1978. Man's conquest of the Pacific: the prehistory of Southeast Asia and Oceania. Oxford: Oxford University Press.

Bellwood, P., Fox, J. J. and Tryon, D. 1995. The Austronesians: Historical and Comparative Perspectives. Canberra: Australian National University Press.

Brandão, A., et al. 2016. Quantifying the legacy of the Chinese Neolithic on the maternal genetic heritage of Taiwan and Island Southeast Asia. Human Genetic 135, 363-376.

Braun, A. 1996. Häufigkeit und Verteilung von Erkrankungen bei zwei Naturvölkern Neuguineas. Berlin: Verlag für Wissenschaft und Bildung.

Broekhuijse, J. T. 1967. De Wiligman-Dani. Een cultureel-anthropologische studie over religie en oorlogvoering in de Baliem- vallei. Doctoral Dissertation, University of Utrecht. H. Gianotten, Tilburg.

Bromley, M. 1967. The Linguistic Relationships of Grand Valley Dani: A LexicoStatistical Classification. Oceania 37: 286-308.

Brongersma, L. D., Venema, G. F. 1960. Het Witte hart van Nieuw Guinea. Met de nederlandse expeditie naar het Sterrengebergte. Amsterdam: Scheltens and Giltay.

Brown, P., Sutikna, T., Morwood, M.J., Soejono, R. P., Jatmiko, Saptomo Wayhu, E., Rokus Awe Due. 2004. Anew small-bodied hominin from the Late Pleistocene of Flores, Indonesia. Nature 431, 1055-1061. 
Brumbaugh, R. 2005. Afek Sang. The Old Woman's Legacy to the Mountain-Ok. In: Pawley, A., Attenborough, R., Golson, J. and Hide, R. (Eds.), Papuan Pasts: cultural, linguistic and biological histories of Papuan-speaking peoples. Pacific Linguistics. Research School of Pacific and Asian Studies. The Australian National University, Canberra, pp.54-87.

Büchi, E. 1981. Physische Anhropologie der Eipo im zentralen Bergland von Irian Jaya West-Neuguinea, Indonesien. Berlin: Reimer.

David Bulbeck. 2008. An Integrated Perspective on the Austronesian Diaspora: The Switch from Cereal Agriculture to Maritime Foraging in the Colonisation of Island Southeast Asia. Australian Archaeology 67: 31-52.

Bulmer, S. 2005. Reflections in Stone: Axes and the Beginnings of Agriculture in the Central Highlands of New Guinea. In: Pawley, A., Attenborough, R., Golson, J. and Hide, R. (Eds.), Papuan Pasts: cultural, linguistic and biological histories of Papuan- speaking peoples. Pacific Linguistics. Research School of Pacific and Asian Studies. The Australian National University, Canberra: 387-450.

Bulmer, S., Bulmer, R. 1964. The prehistory of the Australian New Guinean Highlands. In: Watson, J.B. Ed. New Guinea: the Central Highlands. American Anthropologist 66 (4), 2(special publication), 39-7.

Cavalli-Sforza, L.L., Menozzi, P. and Piazza, A. 1994. The History and Geography of Human Genes. Princeton: Princeton University Press.

Chauvet, S. 1930. Les arts indigènes en Nouvelle-Guinée. Société d'éditions géographiques, maritime et coloniales, Paris.

Craig, B. 1967. The Houseboards of the Telefomin Subdistrict, New Guinea. Man 2: 260-273.

Craig, B., Hyndman, D., Eds. 1990a. Children of Afek. Tradition and Change among the Mountain Ok of Central New Guinea. Oceania Monographs 40, University of Sydney.

Craig, B. and Hyndman, D. 1990b. Introduction. In: Craig, B. and Hyndman, D., Eds. Children of Afek. Tradition and Change among the Mountain Ok of Central New Guinea. Oceania Monographs 40, University of Sydney: 1-8.

Delloye, G. 1977. La hache de Pierre. Raid chez les Papous. Guilde Européenne du Raid, Fernand Nathan, Paris.

Denham, T. P., Haberle, S. G., Lentfer, C., Fullagar, R., Field, J., Therin, M., Porch, N., Winsborough, B. 2003. Origins of agriculture at Kuk Swamp in the Highlands of New Guinea. Science, 301: 189-93.

Dempwolff, O. 1927. Das austronesische Sprachgut in den melanesischen Sprachen. Folia ethno-glossica III, 2, 3, 4.

Dempwolff, O. 1929. Das austronesische Sprachgut in den polynesischen Sprachen. Koninklijk Bataviaasch Genootschap van Kunsten en Wetenschappen, Feestbundel l: 62-86.

Dempwolff, O. 1931. Einige Probleme der vergleichenden Erforschung der SüdseeSprachen. Anthropos XXVI: 157-170. 
Denham, T. 2005. Agricultural origins and the emergence of rectilinear ditch networks, Highlands of New Guinea. In: Pawley, A., Attenborough, R., Golson, J. and Hide, R. (Eds.), Papuan Pasts: cultural, linguistic and biological histories of Papuan-speaking peoples. Pacific Linguistics. Research School of Pacific and Asian Studies. The Australian National University, Canberra: 329-361.

Denham, T. 2011. Early Agriculture and Plant Domestication in New Guinea and Island Southeast Asia. Current Anthropology 52, Supplement 4, S379-S395.

Denham, T., Donahue, M. 2012. Letter. Lack of correspondence between AsianPapuan genetic admixture and Austronesian language dispersal in eastern Indonesia, Proceedings of the National Academy of Science USA 109 (39), E2577.

Dennell, R., Porr, M. (Eds.). South Asia, Australia and the search for human origins. Cambridge: Cambridge University Press.

Dijk, N., van. 2005. Biological relationships amongst New Guinean populations and between New Guinean and Australian populations: the skeletal evidence. In: Pawley, A., Attenborough, R., Golson, J. and Hide, R. (Eds.), Papuan Pasts: cultural, linguistic and biological histories of Papuan-speaking peoples. Pacific Linguistics. Research School of Pacific and Asian Studies. The Australian National University, Canberra: 789-817.

Donohue, D., Crowther, M. 2005. Meeting in the middle: interaction in North-Central New Guinea. In: Pawley, A., Attenborough, R., Golson, J. and Hide, R. (Eds.), Papuan Pasts: cultural, linguistic and biological histories of Papuan-speaking peoples. Pacific Linguistics. Research School of Pacific and Asian Studies. The Australian National University, Canberra, pp. 167-184.

Drabbe, P. 1950. Twee dialecten van de Awyu-taal. Bijdragen tot de Taal-, Land-en Volkenkunde 105: 93-147.

Dubois, E. 1894.PithecanthropusErectus. EinemenschenaehnlicheUebergangsform aus Java. Landesdruckerei, Batavia.

Dyen, I. 1965. A lexicostatistical classification of the Austronesian languages. Indiana University Publications in Anthropology and Linguistics, International Journal of American Linguistics, Memoir 19, Supplement of the International Journal of American Linguistics 31,1.

Easteal, S., Whittle, B., Mettenmeyer, A. Attenborough, R. Bhatia, K. and Alpers, M. P. 2005. Mitochondrial genome diversity among Papuan-speaking people of New Guinea. In: Pawley, A., Attenborough, R., Golson, J. and Hide, R., (Eds.), Papuan Pasts: cultural, linguistic and biological histories of Papuanspeaking peoples. Pacific Linguistics. Research School of Pacific and Asian Studies. The Australian National University, Canberra, pp. 717-728.

Egloff, B. 2008. Bones of the Ancestors. The Ambum Stone: From the New Guinea Highlands to the Antiquities Market to Australia. Lanham: Alta Mira Press.

Erikson, E. H. 1966. Ontogeny of ritualization in Man. Philosophical Transaction of the Royal Society London B251: 337-349.

Fairbairn, A.S., Hope, G.S., Summerhayes G.R. 2006. Pleistocene occupation of New Guinea's highland and subalpine environments. World Archaeology 38(3): 371-386. 
Fairyo, K. 2013 . Makna Motif Lukisan dalam Gua pada Aktivitas Budaya Orang Web di Kampung Yuruf, Distrik Web, Kabupaten Keerom, Thesis, Universitas Cenderawasih Jayapura.

Foley, W. A. 2005. Linguistic prehistory in the Sepuk-Ramu basin. In: Pawley, A., Attenborough, R., Golson, J. and Hide, R., (Eds.), Papuan Pasts: cultural, linguistic and biological histories of Papuan-speaking peoples. Pacific Linguistics. Research School of Pacific and Asian Studies. The Australian National University, Canberra, pp. 109-144.

Gaisseau, P. D. 1961. Le ciel et la boue. Ardennes Films. (Documentary Film).

Gardner, R., Heider, K.G. 1969. Gardens of War: Life and Death in the New Guinea Stone Age. Andre Deutsch, London.

Golson, J. 1976. Archaeology and agricultural history in the New Guinea Highlands. In: Sieveking, G. de, Longworth, L.A. and Wilson, K.E., Eds. Problems in economic and social archaeology. Duckworth, London, pp. 201-220.

Golson, J. 2005. Introduction to the chapters on archaeology and ethnology. In: Pawley, A., Attenborough, R., Golson, J. and Hide, R., Eds. Papuan Pasts: cultural, linguistic and biological histories of Papuan-speaking peoples. Pacific Linguistics. Research School of Pacific and Asian Studies. The Australian National University, Canberra: 221-233.

Haberle, S.G. 2003. The emergence of an agricultural landscape in the highlands of New Guinea. Archaeology in Oceania 38, 149-268.

Hampton, O. W. 1999. Culture of Stone. Sacred and Profane Uses of Stone in the Dani. Texas A and M University Press, College Station.

Harley, N., Attenborough, R., Alpers, M. P., Mgone, C., Bhatia, K. and Easteal, S. 2005. The importance of human patterns of human genetic diversity: Y-chromosome and mitochondrial genome variation in Papuan-speaking people of mainland Papua New Guinea. In: Pawley, A., Attenborough, R., Golson, J. and Hide, R., Eds. Papuan Pasts: cultural, linguistic and biological histories of Papuan-speaking peoples. Pacific Linguistics. Research School of Pacific and Asian Studies. The Australian National University, Canberra, pp. 729-755.

Hariono, B. 2003. Tamu dari langit. Jakarta: Infojec.

Hays, T. 1991. No tobacco, no hallelujah: missions and the early history of tobacco in Eastern New Guinea. Pacific Studies 14: 91-112.

Hays, T. E. (Ed.). 1991. Encyclopedia of World Cultures, Volume II, Oceania. G.K. Hall and Co, Boston.

Hays, T. E. 2005. Vernacular names for tubers in Irian Jaya: implications for agricultural prehistory. In: Pawley, A., Attenborough, R., Golson, J. and Hide, R., Eds. Papuan Pasts: cultural, linguistic and biological histories of Papuanspeaking peoples. Pacific Linguistics. Research School of Pacific and Asian Studies. The Australian National University, Canberra: 625-670.

Healey, A. 1964. The Ok Language Family of New Guinea. PhD Thesis, Linguistics. Australian National University, Canberra. 
Heeschen, V. 1990. Ninye bún. Mythen, Erzählungen, Lieder und Märchen der Eipo im zentralen Bergland von Irian Jaya West- Neuguinea, Indonesien. Berlin: Reimer.

Heeschen, V. 1992. A Dictionary of the Yale Kosarek Language. Berlin: Reimer.

Heeschen, V. 1994. Mythen und Wandergeschichten der Mek-Leute im Bergland von West-Neuguinea Irian jaya, Indonesien. In: Hauser-Schäublin Ed. Geschichte und mündliche Überlieferung in Ozeanien. Basler Beiträge zur Ethnologie, Vol. 37: 161-184.

Heeschen, V., Schiefenhövel, W. 1983. Wörterbuch der Eipo-Sprache. EipoDeutsch-Englisch. Berlin: Reimer.

Heider, K. G. 1970. The Dugum Dani. A Papuan Culture in the Highlands of WestNew Guinea. Chicago: Aldine Publishing C.

Helmcke, D. 1978. Vorläufige Ergebnisse. Forschungen im Bergland von Neuguinea. Das interdisziplinäre West-Irian-Projekt Geologie., Nr. 4. Steinzeit-heute. Berlin: Museum für Völkerkunde.

Hiepko, P., Schiefenhövel W. 1987. Mensch und Pflanze. Ergebnisse ethnotaxonomischer und ethnobotanischer Untersuchungen bei den Eipo, zentrales Bergland von Irian Jaya West-Neuguinea., Indonesien. Berlin: Reimer.

Hill, A.V.S., Serjeantson, S.W., Eds. 1989. The colonization of the Pacific: a genetic trail. Oxford: Clarendon Press.

Hiscock, P., O'Connor, S., Balme, J., Maloney, T. 2016. World's earliest ground-edge axe production coincides with human colonisation of Australia. Australian Archaeology 82, 1: 2-11.

Holdaway, R., Jacomb, C. 2000. Rapid extinction of the moas Aves, Dinornithiformes. Model, test and implications. Science 287: 2250-2254.

Hope, G. S. 1998. Early fire and forest change in the Baliem Valley, Irian Jaya. Journal of Biogeography 25: 453-461.

Hope, G. 2007. The history of human impact on New Guinea. In A. J. Marshall and B. M. Beehler (Eds.), The ecology of Papua: Part 1 (pp. 1087-1097). Singapore: Periplus.

Hope, G.S., Haberle, S.G. 2005. The history of the human landscapes of New Guinea. In: Pawley, A., Attenborough, R., Golson, J. and Hide, R. Eds. Papuan Pasts: cultural, linguistic and biological histories of Papuan-speaking peoples. Pacific Linguistics. Research school of Pacific and Asian Studies. The Australian National University, Canberra: 541-554.

Hope, G., and Aplin, K. 2007. Paleontology of Papua. In A. J. Marshall and B. M. Beehler (Eds.), The ecology of Papua: Part 1 (pp. 246-254). Singapore: Periplus.

Hylkema, S. 1974. Mannen in het draagnet. Mens- en Wereldbeeld van de Nalum, Sterrengebergte. Martinus Nijhoff, S'Gravenhage. (Verhandelingen van het Koninklijk Instituut voor Taal-, Land-, en Volkenkunde 67). 
Hylkema, S. (undated). Nalum-Dutch Dictionary. Unpublished manuscript.

Jorgensen, D. 1991. Telelfolmin. In: Hays, T. E. Hays (Ed.), Encyclopedia of World Cultures, Volume II, Oceania. Boston: G.K. Hall and Co. 321-324.

Jüptner, H. 1983.Tropenmedizinische Untersuchungen der Eipo im zentralen Bergland von Irian Jaya West-Neuguinea, Indonesien. Berlin: Reimer.

Kayser, M., Brauer, S., Weiss, G., Underhill, P.A., Roewer, L., Schiefenhövel, W. and Stoneking, M. (2000). Melanesian Origin of Polynesian Y Chromosomes. Current Biology 10, 20: 1237-1246.

Kayser, M., Brauer, S., Weiss, G., Schiefenhövel, W., Underhill, P., Peidong, S., Oefner P., Tommaseo-Ponzetta, M. and Stoneking, M. 2003. Reduced Y-Chromosome, but Not Mitochondrial DNA, Diversity in Human Populations from West New Guinea. American Joumal of Human Genetics 72: 281-302.

Kayser, M., Brauer, S., Cordaux, R., Casto, A., Lao, O., Zhivotovsky, L.A., MoyseFaurie, C., Rutledge, R.B., Schiefenhövel, W., Gil, D., Lin, A.A., Underhill, P.A. Oefner P.J., Trent, R.J. and Stoneking, M. 2006. Melanesian and Asian Origins of Polynesians: mtDNA and Y. Chromosome Gradients Across the Pacific. Molecular Biology and Evolution 23/11: 2234-2244.

Kayser, M., Choi, Y., van Oven, M., Mona, S., Brauer, S., Trent, R. J., Suarkia, D., Schiefenhövel, W. and Stoneking, M. 2008. The Impact of the Austronesian Expansion: Evidence from mtDNA and $Y$ Chromosome Diversity in the Admiralty Islands of Melanesia. Molecular Biology and Evolution 25/7: 13621374.

Kern, H. 1886. De Fidji-taal vergeleken met hare verwanten in Indonesie en Polynesie. Verhandelingen der Koninklijke Nederlandsche Akademie van Wetenschappen: afdeling Letterkunde, nieuwe reeks, 16, Müller, Amsterdam.

Kirch, P.V. 2010. Peopling of the Pacific: A Holistic Anthropological Perspective. Annual Review of Anthropology 39, 131-148.

Kirk, R.L. 1966. Population genetic studies in Australia and New Guinea. In: Baker, P.T. and Weiner, J.S., Eds. The biology of human adaptability. Oxford: Clarendon Press. 395-430.

Kirk, R.L. 1982. Linguistic, ecological and genetic differentiation in New Guinea and the Western Pacific. In: Crawford, M.H. and Mielke, J.H., Eds. Current developments in anthropological genetics. New York: Plenum Press. 229254.

Kirk, R.L. 1992. Population origins in Papua New Guinea - a human biological overview. In: Attenborough and Alpers, M.P., Eds. Human biology in Papua New Guinea: the small cosmos. Oxford: Clarendon Press. 172-197.

Ko AM, Chen CY, Fu Q, Delfin F, Li M, Chiu HL, Stoneking M, Ko YC: Early Austronesians: into and out of Taiwan. Am J Hum Genet 2014, 94:426-436.

Koch, G. 1977. Anatomie einer Steinzeitkultur. Bild der Wissenschaft 9: 44-59.

Koch, K.-F. 1967. Conflict and its management among the Jalé people of West New Guinea. Doctortal Dissertation. University of California, Berkley reproduced by University Mikrofilms, Ann Arbor. 
Koch, F.-F. 1974. War and Peace in Jalémo. Cambridge: Harvard University Press.

Kock, A.C.M.A. de .1912. Eenige ethnologische en anthropologische gegevens omtrent een drwegstam in het bergland van Zuid Nieuw Guinea. Tijdschrift van het Koninklljk Nederlands Aardrijkskundig Genootschap 29: 154 - 170.

Koenigswald, G.H.R., von. 1955. Begegnungen mit dem Vormenschen. Diederichs, Düsseldorf/Köln.

Leahy, M. J., Crain, M. 1937. The Land That Time Forgot. Adventure and Discoveries in New Guinea. New York: Funk and Wagnalls.

Lipson M, Loh PR, Patterson N, Moorjani P, Ko YC, Stoneking M, Berger B, Reich D: Reconstructing Austronesian population history in Island Southeast Asia. Nature Communications 2014, 5: 4689.

Louwerse, J. 1978 a. Una-English Dictionary. 2nd revised edition with maps and list of verbal categories. Unpublished manuscript.

Louwerse, J. 1978 b. A tentative Una phonology. Irian 7, 3: 43-90.

Louwerse, J. 1988. The morphosyntax of Una in relation to discourse structure: $A$ descriptive analysis. Pacific Linguistics, Series B, vol. 100. Research School of Pacific and Asian Studies. Australian National University, Canberra.

Maffesoli, M. .1966. The Time of the Tribes. Decline of Individualism in Mass Society. London: Sage.

Mahmud, M. I., Novita, E. Djami, I. (Eds.). 2011. Austronesia dan Melanesia di Nusantara: Mengungkap asal-usul dan jati-diri dari temuan arkeologis. Penerbit Ombak, Balai Arkeologi Jayapura.

Mahmud, M.I., Suroto, Hari. 2012. Kajian Arkeologi Kewilayahan Papua: Hasil-Hasil, Strategi dan Prospek. Papua, Jurnal Penelitian Papua dan Papua Barat, IV, 1: 1-8.

Main, P., Attenborough, R., Gao, X. 2005. The origins of the Papuans: The HLA story. In: Pawley, A., Attenborough, R., Golson, J. and Hide, R., Eds. Papuan Pasts: cultural, linguistic and biological histories of Papuan-speaking peoples. Pacific Linguistics. Research School of Pacific and Asian Studies. The Australian National University, Canberra, pp. 757-770.

Malinowski, B. 1922. Argonauts of the Western Pacific. London: Routledge and Kegan Paul.

Marwick, B. 2009. Biogeography of middle Pleistocene hominins in mainland Southeast Asia: a review of current evidence. Quaternary International 2002, 51-58.

Maryone, R., Tolla, M. 2011. Penelitian Arkeologi di Kabupaten Pegunungan Bintang. Laporan penelitian Balai Arkeologi Jayapura.

Maryone, R. 2012. Tradisi Penguburan Prasejarah Suku Ngalum di Kabupaten Pegunungan Bintang. Papua, Jurnal Penelitian Arkeologi IV,1: 9-17.

McElhanon, K., Voorhoeve, C. L. 1970. The Trans-New Guinea Phylum: explorations in deep-level genetic relationships. Pacific Linguistics, Canberra. 
Medicus, G. 2012. Was uns Menschen verbindet. Humanethologische Angebote zur Verständigung zwischen Leib - und Seelenwissenschaften. Verlag für Wissenschaft und Bildung, Berlin.

Mellars, P. 2006. Going East: New Genetic and Archaeological Perspectives on the Modern Human Colonization of Eurasia. Science 313, 796-800.

Mellars, P., Goric, K.C., Carre, M., Soares, P.A., Richards, M.B. 2013. Genetic and archaeological perspectives on the initial modern human colonization of southern Asia. Proceedings of the National Academy of Science USA 110(26), 10699-10704.

Morwood, M. J. Soejono, R. P., Roberts, R. G., Sutikna, T., Turney, C. S. M., Westaway, K. E., Rink, W. J., Zhao, J.-X., van den Bergh, G. D., Rokus Awe Due, Hobbs, D. R., Moore, M. W., Bird, M. I., Fifield, L. K. 2004. Archaeology and age of a new hominin from Flores in eastern Indonesia, Nature 431, 1087-1091.

Nagy, M., Zimdahl, H., Krüger, C., Anders, P., Kayser, M., Roewer, L. and Schiefenhövel, W. 1997. Are the Trobrianders Emigrants of South-East Asia? In: Charron, D., Ed. Genetic Diversity of HLA. Functional and Medical Implications. Proceedings of 12th International Histocompatibility Workshop and Conference, EDK, Paris: 185-188.

O'Connell, J.F., Allen, J. 2004. Dating the colonization of Sahul (Pleistocene AustraliaNew Guinea): a review of recent research. Journal of Archaeological Science 31, 835-853.

O'Connell, J.F., Allen, J. 2015. The process, biotic impact, and global implications of the human colonization of Sahul about 47,000 years ago. Journal of Archaeological Science 56, 73-84.

Oudeyer, PY. and Kaplan, F. 2007. Language evolution as a Darwinian process: computational studies. Cognitive Processing 8,1: 21-35.

Oppenheimer, S. 2014. Modern humans spread from Aden to the Antipodes: With passengers and when? In R. Dennell and M. Porr (eds), Southern Asia, Australia and the Search for Human Origins, pp.228-242. New York: Cambridge University Press.

Pasveer, J. M. 2004. The Djief Hunters. 26,000 Years of Rainforest Exploitation on the Bird's Head Peninsula of Papua, Indonesia. Modern Quartenary Research in Southeast Indonesia 17: VII-337.

Pawley, A. 2005. The chequered career of the Trans New Guinea hypothesis. In: Pawley, A., Attenborough, R., Golson, J. and Hide, R., Eds. Papuan Pasts: cultural, linguistic and biological histories of Papuan-speaking peoples. Pacific Linguistics. Research School of Pacific and Asian Studies. The Australian National University, Canberra, pp. 67-107.

Pawley, A., Attenborough, R., Golson, J. and Hide, R., Eds. 2005. Papuan Pasts: cultural, linguistic and biological histories of Papuan-speaking peoples. Pacific Linguistics. Research School of Pacific and Asian Studies. The Australian National University, Canberra. 
Petrequin, P., Petrequin, A.-M. 1990-1992. Haches de Yeleme, herminettes de Mumyeme. Journal de la Société des océanistes 91: 95-113.

Petrequin, A.-M., Petrequin, P. 2006. Objets de pouvoir en Nouvelle-Guinée. Approche ethnoarchéologique d'un système de signes sociaux. Éditions de la Réunion des musées nationaux, Paris.

Plarre, W. 1978. Forschungsprojekt Biologie der Kulturpflanzen. Forschungen im Bergland von Neuguinea. Das interdisziplinäre West-Irian Projekt, Nr. 26. Steinzeit-heute. Museum für Völkerkunde, Berlin.

Ploeg, A. 2004. The German Eipo Research Project. Journal de la Societé des Océanistes 118: 35-79.

Ploeg, A. 2013. Pouwer's Field Research in the Star Mountains, West New Guinea. Oceania, Vol. 83, 1: 49-56.

Prasetyo, B. 2001. Pola Tata Ruang dan Fungsi Situs Megalitik Tutari, Kecamatan Sentani, Kabupaten Jayapura, Provinsi Irian Jaya. Berita Penelitian Arkeologi 3. Balai Arkeologi Jayapura.

Polanski, J.M., Marsh, H.E., Maddux, S.D. 2016. Dental size reduction in Indonesian Homo erectus: Implications for the PU-198 premolar and the appearance of Homo sapiens on Java. Journal of Human Evolution 90, 49-54.

Pouwer, J. 1964. A social system in the Star Mountains: toward a reorientation of the study of social systems. In: Watson, J. B. (Ed.), New Guinea. The Central Highlands. Special Publication of American Anthropologist 66 part 2: 133161.

Profil Kependudukan Provinsi Papua. 2015. Badan Kependudukan dan Keluarga Berencana, Provinsi Papua, Abepura-Kotaraja.

Rabett, R.J. 2012. Human Adaptation in the Asian Palaeolithic. Hominin Dispersal and Behaviour during the Late Quaternary. McDonald Institute, Cambridge University Press.

Reesink, G. 2005. West Papuan languages: roots and development. In: Pawley, A., Attenborough, R., Golson, J. and Hide, R., Eds. Papuan Pasts: cultural, linguistic and biological histories of Papuan-speaking peoples. Pacific Linguistics. Research School of Pacific and Asian Studies. The Australian National University, Canberra, pp. 185-218.

Ross, Fr.W.A. 1936. Ethnological Notes on Mt. Hagen Tribes (Mandated Territory of New Guinea). With special reference to the tribe called Mogei. Anthropos 31.

Ross, M. 2005. Pronouns as a preliminary diagnostic for grouping Papuan languages. In: Pawley, A., Attenborough, R., Golson, J. and Hide, R., Eds. Papuan Pasts: cultural, linguistic and biological histories of Papuan-speaking peoples. Pacific Linguistics. Research school of Pacific and Asian Studies. The Australian National University, Canberra, pp. 15-65.

Le Roux, C. C. F. M. 1950. De Bergpapoea's van Nieuw-Guinea en hun woongebied. Leiden: Tweede deel Brill.

Saulnier, T. 1960. Les Papous, coupeurs de têtes. 167 jours dans le préhistoire. Paris: Pont Royal. 
Scaglion, R., Soto, K. A. 1994. A prehistoric introduction of the sweet potato in New Guinea?. In: Strathern, A. J. and Stürzenhofecker, G., Eds. Migration and transformations: regional perspectives on New Guinea. Association for Social Anthropology in Oceania Monographs, 15. University of Pittsburgh, Pittsburgh, pp. 257-294.

Schiefenhövel, W. 1976. Die Eipo-Leute des Berglands von Indonesisch-Neuguinea: Kurzer Überblick über den Lebensraum und seine Menschen. Einführung zu den Eipo-Filmen des Humanethologischen Filmarchivs der Max-PlanckGesellschaft. Homo 26 (4): 263-275.

Schiefenhövel, W. 1979. The Eipo - Members of the Mek Group in the Highlands of Irian Jaya. Irian. Bulletin of Irian Jaya Development VII (2): 47-67.

Schiefenhövel, W. 1982. Results of Ethnomedical Fieldwork among the Eipo, Daerah Jayawijaya, Irian Jaya, with Special Reference to Traditional Birthgiving. Medika 11(8): 829-843.

Schiefenhövel, W. 1989. Reproduction and sex-ratio manipulation through preferential female infanticide among the Eipo, in the Highlands of WestNew Guinea. In: Rasa, A., Vogel, Ch. and Voland, E., Eds. The Sociobiology of Sexual and Reproductive Strategies. Chapman and Hall, London, pp.170193.

Schiefenhövel, W. 1991. Eipo. In: Hays, T. E. (Ed.), Encyclopedia of World Cultures, Volume II, Oceania. Boston: G.K. Hall and Co. pp. 55-59.

Schiefenhövel, W. 2001a. Kampf, Krieg und Versöhnung bei den Eipo im Bergland von West-Neuguinea-Zur Evolutionsbiologie und Kulturanthropologie aggressiven Verhaltens. In: Fikentscher, W. Ed., Begegnung und Konflikt eine kulturanthropologische Bestandsaufnahme. Bayerische Akademie der Wissenschaften, Philosophisch-Historische Klasse, Abhandlungen, Neue Folge, Heft 120. C.H. Beck, München: 169-186.

Schiefenhövel, W. 2001b. Sexualverhalten in Melanesien. Ethnologische und humanethologische Aspekte. In: Sütterlin, Ch. and Salter, F. (Hrsg.) Irenäus Eibl-Eibesfeldt. Zu Person und Werk. Bibliotheca Aurea. Peter Lang, Frankfurt a.M., Berlin, Bern, Bruxelles, New York, Oxford: 274-288.

Schiefenhoevel, W. 2004. Trobriands. In: Ember, Carol, R. \& Ember, Melvin, Eds. Encyclopedia of Sex and Gender. Men and Women in the World's Cultures, 2 Volumes. New York, Boston, Dordrecht, London, Moscow: Kluwer Academic/ Plenum Publishers. pp. 912-921.

Schiefenhövel, W. 2009. Romantic love. A human universal and possible honest signal. Human ontogenetics 3, 2 July 2009, open acces journal, Wiley-VCH, Weinheim, 39-50.

Schiefenhövel, W. 2013. Biodiversity through Domestication. Examples from New Guinea. Revue d'ethnoécologie (En ligne), 3, (Alimentation et biodiversité): 2-19.

Schiefenhövel, W. 2014. Human Ethological Perspectives on Prehistoric Adaptation and Dispersal in the Central Highlands of New Guinea. In: Sanz, N., Ed., Human Origin Sites and the World Heritage Convention in Asia. World Heritage Papers 39. UNESCO, Paris and Ciudad de Mexico: 235-254. 
Schiefenhövel, W. 2015. Eipo. In: Feest, Ch., Kron, Ch., (Eds.), Regenwald. Begleitbuch zur Sonderausstellung im Ausstellung Lokschuppen Rosenheim. Theiss, Rosenheim: 170-175.

Schiefenhövel, W., Blum, P. 2007. Insects: Forgotten and Rediscovered as Food. Entomophagy among the Eipo, Highlands of West-New Guinea, and in other Traditional Societies. In: MacClancy, J., Henry, J. and Macbeth, H., Eds. Consuming the Inedible. Neglected Dimensions of Food Choice. New Yok, Oxford: Berghahn Books. pp. 163-176.

Schiefenhövel, W. and Voland, E. 2009. Introduction. In: Voland, E. \& Schiefenhövel, W. (Eds.) The Biological Evolution of Religious Mind and Behavior. Springer, The Frontiers Collection. Dordrecht, Heidelberg, London, New York: 1-7.

Schmidt, W. 1899a. Die sprachlichen Verhältnisse Ozeaniens in ihrer Bedeutung für die Ethnologie. Mitteilungen der Anthropologischen Gesellschaft in Wien $X X I X: 245-258$.

Schmidt, W. 1899b. Über das Verhältnis der melanesischen Sprachen zu den polynesischen und untereinander. Sitzungsberichte der kaiserlichen Akademie der Wissenschaften in Wien, philosophisch-historische Klasse CXLI: VI.

Schwerdtner Manez, K. and Ferse, S. C. A. 2010. The History of Makassan Trepang Fishing and Trade. PLoS One 5 (6): e11346 online, published June 29.

Sémah, A.-M., Sémah, F., Moudrika, R., Fröhlich, F. and Djubiantono, T. (2004). A late Pleistocene and Holocene sedimentary record in Central Java and its palaeoclimatic significance. In: Keates, S.G. and Pasveer, J. (Eds.), Quartenary Research in Indonesia. Baltema, Rotterdam, pp. 63-88.

Sémah, A.-M. and Sémah, F. 2012. The rain forest in Java through the Quaternary and its relationships with humans (adaptation, exploitation and impact on the forest). Quaternary International. Volume 249, 6 February 2012, Pages 120128.

Sémah, F. 1986. Le peuplement ancient de Java-Ébauche d'un cadre chronologique. L'Anthropologie 90(3), 359-400.

Simanuntjak, T. 2004. "Diaspora Austronesia, sebuah pengantar", dalam polemik tentang Masyarakat Austronesia, Fakta atau Fiksi?. Jakarta: LIPI.

Simanuntjak, T. 2011. Austronesia Prasejarah di Indonesia. In: Mahmud, M. I., Novita, Djami, N. I. (Eds.) Austronesia dan Melanesia di Nusantara: Mengungkap asal-usul dan jati-diri dari temuan arkeologis. Penerbit Ombak, Balai Arkeologi Jayapura.

Sinnet, P.F. and Whyte, H.M. 1973. Epidemiological studies in a total highland population, Tukisenta. New Guinea. Cardiovascular disease and relevant clinical, electrocardiographic radiological and biochemical findings. Journal of Chronic Diseases 26, 5: 265-290.

Sneep, J. 2005. Einde van het stenen tijdperk. Bestuursambtenaar in het Witte hart van Nieuw-Guinea. Rozenberg Publication, Amsterdam.

Soares P, et al. 2011. Genetic evidence for early Holocene voyaging between Indonesia and Near Oceania. Am J Hum Genet 88:239-247. 
Soares P, et al. 2011. Resolving the ancestry of Austronesian-speaking populations. Hum Genet 2016 135:309-326.

Solheim, W.G., II. 1976. Coastal Irian Jaya and the origin of the Nusantao Austronesian speaking peoples. In: Serizawa, L. Ed. Le premier peuplement de l'archipel Nippon et des iles du Pacifique. Proceedings of the International Congress of Prehistory and Protohistory. Sciences, Nice, pp. 323-42.

Solheim, W. G. II .1978.Archeological survey, Irian Jaya. Pacific Art Newsletter 1: 207-208.

Solheim, W. G. II .1984.The Nusantao hypothesis: the origin and spread of Austronesian speakers. Asian Perspectives: 77-88.

Sprigss, M. 2011. Archaeology and the Austronesian expansion: Where are we now? Antiquity 85(328), 510-528.

Souter, G. 1963. New Guinea: The Last Unknown. Angus and Robertson, Sydney.

Stoneking, M. and Wilson, A. C.1989. Mitochondrial DNA. In: Hill, A. V. S. and Serjeantson, S., Eds. The colonisation of the Pacific: a genetic trail. Clarendon Press, Oxford: 215-245.

Stout, D. 2002. Skill and Cognition in Stone Tool Production. An ethnographic case study from Irian Jaya. Current Anthropology 43: 693-722.

Stringer, C. 2011. The Origin of Our Species. London: Penguin/Allen Lane.

Summerhayes, G.R., Ford, A., 2014. Late Pleistocene colonisation and adaptation in New Guinea: implications for debates on modern human behavior. In: Dennell R., Porr, M. (Eds.), 2014. Southern Asia, Australia, and the Search for Human Origins, Cambridge: Cambridge University Press.

Suroto, Hari .2011. Bentuk dan Fungsi Gerabah Kawasan Danau Sentani. Papua, Jurnal Penelitian Arkeologi III,: 89-96.

Suroto, Hari. 2013. Revolusi Ubi Jalar di Lembah Baliem. In: Frank, Simon Abdi K. and Mene Bau (Eds.) Kebudayaan Papua. Tradisi, Sistem Pengetahuan, dan Pembangunan Jati Diri. Makassar: Masagena Press. p. 79-94.

Swadling, P. 1981. Papua New Guinea's Prehistory. Trustees of the National Museum and Art Gallery, Port Moresby.

Swadling, P. 1983. How Long Have People been in the Ok Tedi Impact Region? Papua New Guinea Museum Record No. 8, Boroko.

Swadling, P. and Hide, R. 2005. Changing landscapes and social interaction: looking at agricultural history from a Sepik-Ramu perspective. In: Pawley, A., Attenborough, R., Golson, J. and Hide, R., Eds. Papuan Pasts: cultural, linguistic and biological histories of Papuan-speaking peoples. Pacific Linguistics. Research School of Pacific and Asian Studies. The Australian National University, Canberra: 289-327.

Tandjung, F. E. 1969. Laporan team expedisi ilmiah Lembah-X tgl. 2 Okt. s/d tgl. 20 Des. 69 (Report of a military expedition to the Eipomek Valley. Typewritten manuscript in Bahasa Indonesia). Komando Daerah Militer XVII Tjenderawasih, Jayapura. 
Tilburg, J.A. van .1994. Easter/sland; Archaeology, Ecology and Culture. Washington, D.C: Smithsonian Institution Press.

van den Bergh, G.D., Kaifu, Y., Kurniawan, I., Kono, R.T., Brumm, A. Setiyabudi, E., Aziz, F., Morwood, M.J. 2016a. Homo floresiensis-like fossils from the early Middle Pleistocene of Flores, Nature 534, 245-248.

van den Bergh, G. D., Li, B., Brumm, A., Grün, R., Yurnaldi, D., Moore, M. W., and Storey, M. 2016b. Earliest hominin occupation of Sulawesi, Indonesia. Nature 529(7585): 208-211.

van der Sande, G.A J., 1905. De Papua's van Nederlandsch Nieuw-Guinea, Indische Mercuur.

Vanhaeren M. and d'Errico F. 2006. Clinal distribution of personal ornaments reveals the ethno-linguistic geography of Early Upper Palaeolithic Europe. Journal of Archaeological Science 33(8), 1105-1128.

Vanhaeren, M. 2010. Les fonctions de la parure au Paléolithique supérieur: de l'individu à l'unité culturelle. Editions Universitaires Européennes, Sarrebruck.

Vanhaeren, M. and Schiefenhoevel, W. (in preparation) Data base of elements of body decoration in Melanesia.

Vicedom, G.F. and Tischner, H., 3 vols. 1943-1948. Die Mbowamb. Die Kultur der Hagenberg-Stämme im östlichen Zentral-Neuguinea. De Gruyter, Hamburg

Voorhoeve, B. 2005. Asmat-Kamoro, Awyu-Dumut and Ok: an enquiry into their linguistic relationship. In: Pawley, A., Attenborough, R., Golson, J. and Hide, R., Eds. Papuan Pasts: cultural, linguistic and biological histories of Papuanspeaking peoples. Pacific Linguistics. Research School of Pacific and Asian Studies. The Australian National University, Canberra, pp. 145-166.

Wiessner, P. 2005. Social, symbolic, and ritual roles of the sweet potato in Enga, from its introduction until first contact. In: Ballard, C., Brown, P., Bourke, M. and Tracy Harwood, Eds. The Sweet Potato in the Pacific: A reappraisal. Sydney: Ethnology Monographs 19, Oceania Monograph 56, University of Sydney. P. 121-130.

Wirz, P. 1925. Die Marind-anim von Holländisch-Süd-Neuguinea. II. Band, Teil III, Das soziale Leben der Marind-anim. Friedrichsen, Hamburg.

Wright, D., Denham, T., Shine, D., Donohue, M. 2013. An Archaeological Review of Western New Guinea, Journal of World Prehistory 26, 25-73.

Wurm, S.A. 1960. The changing linguistic picture in New Guinea. Oceania 31: 121136.

Wurm, S. A., Ed. 1975. New Guinea area languages. Vol. 1: Papuan languages and the New Guinea linguistic scene. Pacific Linguistics, Canberra.

Xu S, Pugach I, Stoneking M, Kayser M, Jin L; HUGO Pan-Asian SNP Consortium 2012. Genetic dating indicates that the Asian-Papuan admixture through Eastern Indonesia corresponds to the Austronesian expansion. Proc Natl Acad Sci USA 109:4574-4579. 
Zimdahl, H., Schiefenhövel, W., Kayser, M., Roewer, L. and Nagy, M. 1999. Towards understanding the origin and dispersal of Austronesians in the Solomon Sea: HLA class II polymorphism in eight distinct populations of Asia-Oceania. Journal of Immunogenetics 26: 405-416.

Zöllner, S. 1977. Lebensbaum und Schweinekult. Die Religion der Jalî im Bergland von Irian-Jaya West-Neu-Guinea. Theologischer Verlag R. Brockhaus, Darmstadt.

Zöllner, S. (undated) Yali Wörterbuch. Unpublished manuscript.

\section{INTERNET SOURCES}

Lewis, M. Paul (ed.), 2009. Ethnologue: Languages of the World, Sixteenth edition. Dallas, Texas: SIL International. Online version: http://www.ethnologue. com/16. - accessed May 31, 2017. 


\section{Figures}

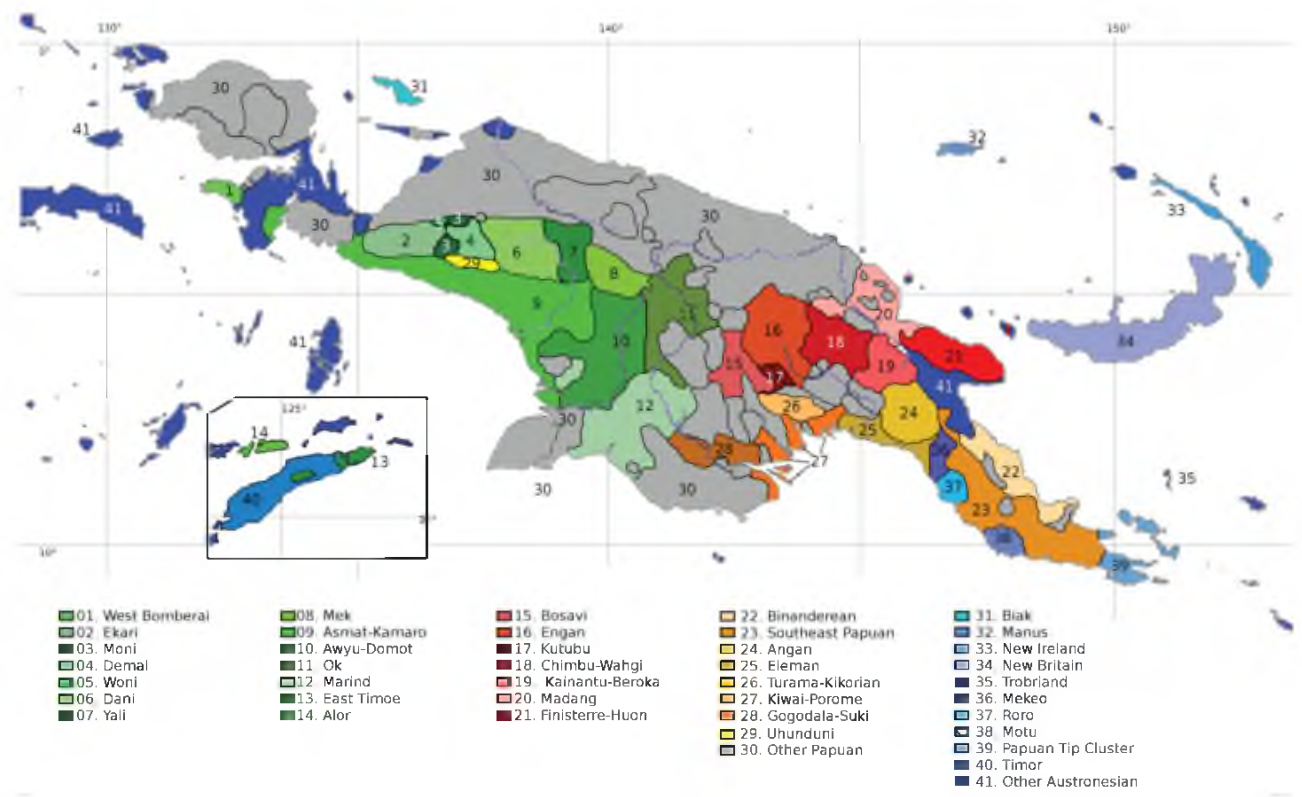

Figure 1.

Map of the distribution of some languages in Melanesia with special reference to ethno-linguistic groups mentioned in the text (after Schiefenhövel 2014).

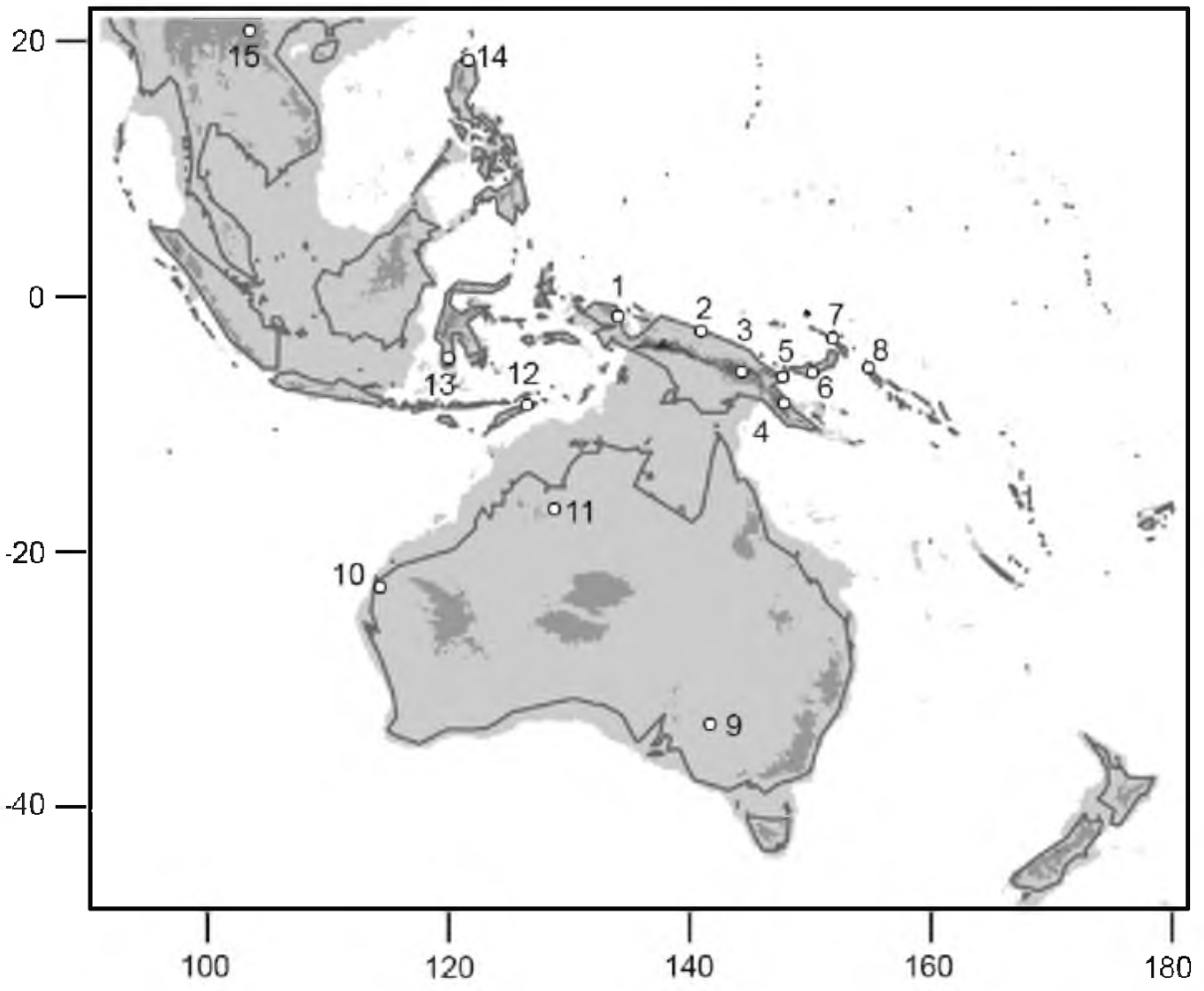

Figure 2

Location of archaeological sites mentioned in the text. 1: Toe Cave, 2: Lachitu, 3: 4: Ivane Valley, 5:

Bobongara, 6: Yombon, 7: Buang Merabak, 8: Kilu Cave, 9: Lake Mungo, 10: Mandu Mandu Cave, 11: Riwi, 12: Jerimalai, 13: Maros, 14: Callao Cave Luzon, 15: Ta Pa Ling. 